\title{
Age, Growth and Maturity of the Commercial Ray Species from the Irish Sea
}

\author{
M. J. Gallagher, C. P. Nolan and F. Jeal \\ Zoology Department, Trinity College, Dublin 2, Ireland
}

Gallagher, M. J., C. P. Nolan, and F. Jeal. 2005. Age, Growth and Maturity of the Commercial Ray Species from the Irish Sea. J. Northw. Atl. Fish. Sci., 35: 47-66. doi:10.2960/J.v35.m527

\begin{abstract}
The age, growth and maturity of 1554 individuals (268 Raja brachyura, 258 R. clavata, 468 $R$. montagui and 560 Leucoraja naevus) of the main commercial ray species from the Irish Sea were determined from samples taken from commercial and research trawls between 1997 and 1998. Sagittal sections of vertebral centra stained using crystal violet enhanced the underlying band patterns of each species, allowing the derivation of age and von Bertalanffy growth parameters. Age estimates were relatively low for each species, with a maximum age of $7 \mathrm{yr}$ recorded for $R$. montagui and $8 \mathrm{yr}$ for each other species. Growth rate parameters ranged between $K=0.093\left(L_{\infty}=139.500\right.$ and $\left.t_{0}=-1.841\right)$ for female $R$. clavata and $K=0.304\left(L_{\infty}=72.400\right.$ and $\left.t_{0}=-0.924\right)$ for male $R$. montagui, and were notably higher for both the smaller growing $R$. montagui and $R$. naevus. Morphological assessment of maturity, revealed that; male $R$. montagui matured at the smallest size $(53.651 \mathrm{~cm})$ and earliest age $(3.410 \mathrm{yrs})$, male and female $R$. clavata matured at the greatest age $(6.130 \mathrm{yrs})$ and female $R$. brachyura matured at the largest size $(83.560 \mathrm{~cm})$. In each species, an abrupt increase in clasper size in males and nidamental gland width in females was closely associated with the onset of maturity. Age, growth and maturity are discussed for each species with respect to previous studies and observed trends in the fishery.
\end{abstract}

Key words: age, fishery, growth, Irish Sea, maturity, rays, vertebrae

\section{Introduction}

The Irish Sea ray fishery is an important, long established resource, with rays considered as 'prime fish' at U.K. fish markets since the early-1900s (Steven, 1936). Although 11 species have been recorded in these waters, only the blonde ray, Raja brachyura, the thornback ray, $R$. clavata, the spotted ray, R. montagui, and the cuckoo ray, Leucoraja naevus are of commercial importance (Fahy, 1989). These are landed as a mixed species assemblage, by size grade, from both a by-catch, and a seasonally directed bottom trawl fishery (Holden, 1977; Fahy, 1989). U.K. landings have declined, over the last $10 \mathrm{yrs,} \mathrm{owing}$ largely to reductions in fleet size (Brander, 1988; Corlett, 1990). Conversely, Irish landings have increased in recent decades and annual ray landings consistently constitute over $10 \%$ of the total demersal landings in the Irish Sea (Fahy, 1989, Gallagher, 2000).

Unlike many of the commercially exploited teleost species that have shown major declines as a result of longterm intensive exploitation in the Irish Sea (Armstrong and Briggs, 1993; Anon., 1999a) the aggregated landings of rays, although variable, have remained relatively stable over the past 60 years (Brander, 1988; Fahy, 1989, 1991; Dulvy et al., 2000). Nonetheless, changes in the relative abundance of certain species are evident, with the virtual disappearance of the large common and long-nosed skates, $R$. batis and R. oxyrhincus, (Brander, 1981; Holden, 1977; Dulvy et al., 2000) and the reduction in both the abundance and size distribution of the moderately sized thornback ray (Holden, 1974; Fahy, 1989; Dulvy et al., 2000). Furthermore, evidence suggests that the small spotted and cuckoo rays have increased in abundance (Holden, 1977; Fahy, 1989; Dulvy et al., 2000). This phenomenon has also been observed in the North Sea ray fishery, and it has been suggested that smaller more resilient, less $k$ selected species, have a more selective survival advantage relative to the larger species (Walker and Hislop, 1998). It has also previously been reported that changes in stock structures and densities, through long-term exploitation, can alter life history traits of elasmobranchs (Tanaka et al., 1990; Officer et al., 1996). Walker (1999) noted this for the thornback ray in the North Sea, where the growth rate had increased and the age-at-maturity had decreased over a thirty-year period.

Historical evidence also suggests that similar changes in the growth and maturity of rays from the Irish Sea have occurred. Particularly rapid growth has been recorded for the two smaller commercial species, the spotted and cuckoo rays (Fahy, 1989), with growth rates almost double those reported in previous studies for the spotted ray (Holden, 1972; Ryland and Ajayi, 1984). In addition, 
maturity estimates also indicate that both the size- and age-at-maturity have also decreased for the thornback ray over a sixty-year period (Stevens, 1936; Williams et al., 1965; Nottage and Perkins, 1983; Ryland and Ajayi, 1984).

Difficulties often arise for elasmobranchs when comparing species-specific growth and maturity estimates between studies (Cailliet, 1990; Cailliet et al., 1990; Tanaka et al., 1990). Differing methodologies together with inadequate or incomplete sample sizes or ranges prevent the true comparison of estimates and present difficulties in determining whether observed differences are biological or methodological (Stevens, 1936; Williams et al., 1965; Nottage and Perkins, 1983; Ryland and Ajayi, 1984; Fahy, 1989). These difficulties are also evident when previous growth and maturity studies of the Irish Sea ray species (Tables 1 and 2) are examined (Stevens, 1936; Williams et al., 1965; Nottage and Perkins, 1983; Ryland and Ajayi, 1984; Fahy, 1989). In particular, the most recent growth estimates derived for the commercial ray species (Fahy, 1989), which strongly suggested rapid growth for the smaller species are confounded by restricted sampling, as samples were collected from the commercial landings only and no enhancement techniques were used to resolve bands for age assessment purposes. Furthermore, the significance of the various maturity estimates is difficult to ascertain, as differing maturity indices and limited sample sizes are evident (Stevens, 1936; Williams et al., 1965; Nottage and Perkins, 1983; Ryland and Ajayi, 1984).

Holden and Vince's (1973) tetracycline tag-recapture study of the thornback ray in the southern North Sea was the first to validate annual band formation in the vertebral centra of elasmobranchs. Although it was suggested, that the opaque bands form from July to November, and that November marked the changeover from opaque to translucent band formation, there were uncertainties about these assumptions. This was largely due to the poor temporal range of the samples collected owing to the seasonal nature of the fishery along with the fact that connective tissue obscured the visualisation of bands forming at the periphery of the vertebral centrum. Although it is recommended that the temporal nature of band formation should be established for differing stocks of a given species to determine the rate and timing of growth band deposition (Cailliet, 1990) this has not yet been determined for Irish ray species.

This study focuses on the derivation of comprehensive age, growth and maturity estimates for each of the Irish Sea commercial ray species and discusses the findings in relation to previous studies and the current status of the fishery at the species level.

TABLE 1. von Bertalanffy growth parameters for Irish Sea ray species $\left(L_{\infty}=\right.$ theoretical maximum length, $K=$ Brody growth coefficient and $t_{0}=$ theoretical age at which length is zero). (* Denotes range of growth rate parameters derived by Fahy (1991)).

\begin{tabular}{|c|c|c|c|c|c|}
\hline Species & Sex & $L_{\infty}$ & $K$ & $t_{0}$ & References \\
\hline R. brachyura & $\mathrm{F}$ & 118.4 & 0.19 & -0.8 & Holden (1972) \\
\hline R. brachyura* & $\mathrm{F}$ & $120.0-144.3$ & $0.19-0.29$ & $-0.31-+0.15$ & Fahy (1991) \\
\hline R. brachyura & M & 115 & 0.19 & -0.18 & Holden (1972) \\
\hline R. brachyura* & M & $116.7-119.4$ & $0.24-0.26$ & $-0.31-+0.15$ & Fahy (1991) \\
\hline R. clavata & both & 139.2 & 0.09 & -2.63 & Ryland and Ajayi (1984) \\
\hline R. clavata & both & 105 & 0.22 & 0.45 & Brander and Palmer (1985) \\
\hline R. clavata & $\mathrm{F}$ & 127.3 & 0.1 & -2.5 & Taylor and Holden (1964) \\
\hline R. clavata & $\mathrm{F}$ & 107 & 0.13 & -0.6 & Holden (1972) \\
\hline R. clavata* & $\mathrm{F}$ & $107.8-120$ & $0.15-0.26$ & $-1.01-+0.05$ & Fahy (1991) \\
\hline R. clavata & M & 88.3 & 0.22 & -1.3 & Taylor and Holden (1964) \\
\hline R. clavata & M & 85.6 & 0.21 & -0.6 & Holden (1972) \\
\hline R. clavata* & $\mathrm{M}$ & $96.8-104.3$ & $0.19-0.24$ & $-1.36-+0.32$ & Fahy (1991) \\
\hline R. montagui & both & 97.8 & 0.15 & -1.72 & Ryland and Ajayi (1984) \\
\hline R. montagui & $\mathrm{F}$ & 72.8 & 0.18 & -0.37 & Holden (1972) \\
\hline R. montagui & $\mathrm{F}$ & 74 & 0.24 & -2.72 & Fahy (1991) \\
\hline R. montagui & M & 68.7 & 0.19 & 0.56 & Holden (1972) \\
\hline R. montagui & M & 68.2 & 0.33 & -1.87 & Fahy (1991) \\
\hline R. naevus & $\mathrm{F}$ & 73.1 & 0.23 & -2.47 & Fahy (1991) \\
\hline R. naevus & M & 69.9 & 0.33 & -1.12 & Fahy (1991) \\
\hline
\end{tabular}


TABLE 2. Size (total length $(\mathrm{cm})$ ) and age-at-maturity (yr) estimates for Irish Sea ray species. (* Denotes total length estimates based on conversion of disc-width, using conversion factors calculated in this study.)

\begin{tabular}{lcccl}
\hline \hline Species & Sex & Length-at-maturity $(\mathrm{cm})$ & Age-at-maturity $(\mathrm{yr})$ & Study \\
\hline R.clavata & both & 60 & 5 & Ryland and Ajayi (1984) \\
R.clavata & $\mathrm{F}$ & $90-97^{*}$ & 9 & Steven (1936) \\
R.clavata & $\mathrm{F}$ & $71^{*}$ & & Williams et al., (1965) \\
R.clavata & $\mathrm{F}$ & 65 & & Nottage and Perkins (1983) \\
R.clavata & $\mathrm{M}$ & $72^{*}$ & 7 & Steven (1936) \\
R.clavata & $\mathrm{M}$ & $62^{*}$ & & Williams et al., (1965) \\
R.clavata & $\mathrm{M}$ & 60 & 5 & Nottage and Perkins (1983) \\
R. montagui & both & 60 & 5 & Ryland and Ajayi (1984) \\
\hline
\end{tabular}

\section{Methods}

Specimens were collected from commercial landings and research surveys from the Irish Sea (from ICES Statistical Division VIIa) between 1996 and 1998 as follows: 127 male and 141 female blonde rays, 165 male and 93 female thornback rays, 274 male and 194 female spotted rays and 351 male and 209 female cuckoo rays. Species, sex, total length $(\mathrm{cm})$, disc width, ungutted and gutted weight $(\mathrm{g})$ maturity status, clasper length $(\mathrm{cm})$ in males, and nidamental gland width $(\mathrm{mm})$ in females, were recorded.

\section{Age and Growth}

A vertebral segment containing approximately 10 vertebrae was extracted, from each sample collected, immediately posterior to the scapular origin of the vertebral column. Tissue was removed by immersing the segments in hot water (circa. $70-85^{\circ} \mathrm{C}$ ). Segments were subsequently air-dried and then immersed in a 5\% solution of trypsin (hog pancreatin) at $35-40^{\circ} \mathrm{C}$ for 24 hours, to remove the neural and haemal arches, and the connective tissue from the vertebral fascia. Following this process, centra were washed for 30 minutes in running water.

In order to fully appraise the effectiveness of each enhancement technique examined, a sample of centra from each species was processed in a variety of forms (e.g. whole, whole scraped and etched, sagittal sections). An extensive range of enhancement techniques, described in Gallagher (2000), was applied to each centrum preparation. The most effective technique was a modification of the crystal violet staining technique described by Schwartz (1983). Sagittal sections were prepared from the two largest centra from each specimen. Sections were etched by immersion in an acid alcohol (IMS) solution (5\%) for 15 minutes, and were subsequently washed for 15 minutes in running water. Sections were then placed in a $0.005 \%$ solution of crystal violet for 36 hours, and checked every 12 hours for stain uptake. Stained sections were then washed in running water for 2 minutes. Over-stained sections were de-stained for 2-4 minutes in an alcohol solution $(70 \%)$.

For age reading purposes a growth increment or 'band' on a sagittal section was defined as a heavily stained opaque band appearing at relatively regular intervals along the corpus calcareum, and separated by a translucent band. As the intermedialia was often over-stained or ground away, the majority of band counts were derived from counts of the heavily stained bands on the corpus calcareum. The birth or hatching mark (age zero) was defined as the first mark after the change in the angle of the corpus calcareum. All age readings were made from the focus towards the distal edge on a single axis exhibiting greatest resolution. Band counts were corroborated with readings made along the remaining three axes.

Prepared centra were viewed on three separate occasions independently under a dissecting microscope using both transmitted and reflected light, without prior knowledge of species, sex, size, maturity and date of capture. A sub-sample of centra was read by a second and third reader independently, on three separate occasions. Each of the two readers used the same criteria as the primary reader to count bands. Coefficient of variation $(V)$, which describes the standard deviation as a percentage of the mean and the index of precision $(D)$ (Chang, 1982) were determined for reader estimates of age.

Bands forming at the edge of stained sagittal sections were characterised as belonging to one of the three following stages of formation (Yudin and Cailliet, 1990):

Grade 1. Centrum: Opaque band forming at the marginal edge

Grade 2. Centrum: Narrow, translucent band forming at the edge

Grade 3. Centrum: Translucent band well formed on the marginal edge 
For each species, length and age data were logged, and analyses of covariance (ANCOVA) were carried out to establish whether significant differences existed in the length and age estimates between the sexes of each species. The von Bertalanffy (1938) growth model was fitted to the data using nonlinear regression. Fishparm (Prager et al., 1987), which implements Marquardt's algorithm for nonlinear, least squares, parameter estimation (Marquardt, 1963), was chosen to fit the growth curves to the data sets, and also calculated standard error and goodness of fit $\left(r^{2}\right)$.

\section{Maturity}

Maturity of each individual was assessed using a modification of Stehmann's (1987) maturity scale for elasmobranchs (Table 3). The logistic model (Fishparm (Prager et al., 1987)) was used to estimate the length and age at which $50 \%$ of each species examined attained maturity. Males and females assessed as stage 3 and 4, respectively, in the maturity index were deemed mature for the analysis.

Clasper length $(\mathrm{cm})$ and total length $(\mathrm{cm})$ were plotted for males and nidamental gland width $(\mathrm{mm})$ was also plotted against total length $(\mathrm{cm})$ for females to ascertain the relationship between body size and sexual development.

\section{Results}

\section{Age and Growth}

Crystal violet staining of sagittal sections proved to be the most effective enhancement technique for all species in the study and had a number of distinct advantages over the other techniques tested. Principal amongst these was a single stage in the staining protocol. As a result the effects of altering the stain concentration or the immersion time could be readily ascertained and the desired intensity of staining carefully controlled. In addition de-staining of over-stained sections was accomplished, using alcohol.

Each species had a similar band morphology, with opaque bands appearing as relatively thick regularly spaced dark coloured bands along each sagittal sections axis, separated by narrower lighter coloured translucent bands (Fig. 1).

For each species opaque band formation was generally associated with the mid-summer autumn growth phase (June-October). This was evident for the blonde ray (Fig. 2), with opaque band formation (Grade 1) being dominant from July to September $(100 \%)$ and for the thornback ray (Fig. 3), where band formation (Grade 1) also developed during the summer-autumn growth cycle (June 10\%, August $70 \%$ ). However, a discontinuity in the cycle of band formation was evident in the thornback ray, with translucent band formation (Grade 2) being dominant in September (67\%), and opaque band formation (Grade 1) being dominant in November (78\%). It is probable that this discontinuity was due to a combination of a small sample size in September, and interpretational difficulties at the distal margins. For the spotted ray (Fig. 4) opaque band formation (Grade 1) became more discernible from July (14\%) to October (100\%). A similar trend was also apparent for the cuckoo ray (13\% in July, $80 \%$ in September) (Fig. 5). Opaque band formation may be complete at an earlier stage in the cuckoo ray than the spotted ray, as all the spotted rays examined were forming an opaque band in October, whereas the formation of translucent bands (Grade 2) had commenced in the cuckoo ray (43\%).

The autumn-winter transition (October-November) generally marked the changeover from opaque to translucent band formation for each species. This was particularly apparent for the two smaller sized spotted (Fig. 4) and cuckoo ray species (Fig. 5). Opaque band formation (Grade 1) dominated both the spotted and cuckoo rays sampled in October $(100 \%$ and $57 \%$, respectively). However, the transition to translucent band formation occurred for both species in November with forming translucent bands (Grade 2) being evident in equal proportions (38\%) to fully formed bands (Grade 3 ) for the spotted ray, and forming bands dominating the cuckoo rays sampled (73\%). The trend of translucent band formation became more evident with the proportions of forming (Grade 2) and fully formed (Grade 3) translucent bands increasing further in December for both species (Fig. 4 and 5), whereas opaque band formation was not evident. For the blonde ray (Fig. 2) the changeover from opaque to translucent band formation was also evident from October to November with a drop in the proportion of opaque bands (Grade 1, 69\% to 13\%) and an increase in the proportion of forming translucent bands (Grade 2, $31 \%$ to $87 \%$ ). Unfortunately no samples were examined in December to assess whether this trend continued. Due to limited sample sizes, a clear trend is not as discernible for the thornback ray from October to November. However the proportion of opaque bands dropped (Grade 1, 78\% to $25 \%$ ) and translucent forming bands increased (Grade 2, $22 \%$ to $75 \%$ ) from November to December.

For each species fully developed translucent bands (Grade 3) were more evident towards the end of spring and entering summer. This was evident in the May-June samples for both the cuckoo (May 93\%, June 85\%) and the spotted rays (May $50 \%$, June $80 \%$ ). Although fully formed 
TABLE 3. Maturity indices (modification of Stehmann's scale 1987) used in the assessment of maturity of Raja brachyura, R. clavata, R. montagui, R. naevus.

\begin{tabular}{|c|c|}
\hline Male & Female \\
\hline $\begin{array}{l}\text { 1. Juvenile } \\
\text { Claspers less than the length of the pelvic fins. Testis } \\
\text { undeveloped, thread or leaf-like. Spermatophoric area } \\
\text { present as leaf-like zone within the testis. Sperm duct } \\
\text { undeveloped. Kidneys evident. } \\
\text { 2. Adolescent, Maturing } \\
\text { Claspers longer than tips of pelvic fins. Clasper tips (glans) } \\
\text { already structured but skeleton still flexible. Testis swollen } \\
\text { with developing spermatophoric spheres. Sperm ducts with } \\
\text { obvious structure and uniform size throughout. Kidneys } \\
\text { slightly obscured by developing sperm duct. } \\
\text { 3. Adult, Mature } \\
\text { Claspers rigid and much longer than pelvic fins, glans } \\
\text { structure fully formed. Testis swollen with developing } \\
\text { spermatophoric spheres. Sperm ducts with obvious } \\
\text { structure, separated into two distinct sections and filled } \\
\text { with flowing sperm. Sperm duct obscuring at least half of } \\
\text { kidneys. } \\
\text { 4. Adult, Running } \\
\text { Glans clasper often dilated, its structure reddened and } \\
\text { swollen. Sperm flowing on pressure from cloaca and/or } \\
\text { present in clasper groove or glans. Testis swollen with } \\
\text { developing spermatophoric spheres. Sperm duct with } \\
\text { obvious structure, separated into two distinct regions. } \\
\text { Sperm duct obscuring majority of kidneys. }\end{array}$ & $\begin{array}{l}\text { 1. Juvenile } \\
\text { Ovaries leaf-like, thin. No obvious eggs present in opaque } \\
\text { zone within ovary with gelatinous or granular appearance. } \\
\text { Nidamental glands undeveloped, present as opaque bulge } \\
\text { in oviduct. Oviduct small and thread-like. } \\
\text { 2. Adolescent, Maturing } \\
\text { Ovaries containing small eggs. Nidamental gland small } \\
\text { and developing, cream in colour with obvious white ends. } \\
\text { Oviducts small and thread-like. } \\
\text { 3. Adult, Developing } \\
\text { Ovaries containing developing eggs some of which are } \\
\text { very large. Nidamental gland fully developed, uniformly } \\
\text { white. Ovary walls thickened. } \\
\text { 4. Adult, Mature } \\
\text { Ovaries containing large eggs. Large eggs present in } \\
\text { fallopian tubes, or already passing through to nidamental } \\
\text { gland. Nidamental gland fully developed. Egg cases if } \\
\text { present, only partially extruded. Oviducts developed, walls } \\
\text { thick and venous. } \\
\text { 5. Adult, Laying } \\
\text { Ovaries containing large eggs. Nidamental glands fully } \\
\text { developed, uniformly white. Fully formed eggs present. } \\
\text { Oviducts developed, wall thick and venous or may appear } \\
\text { stretched (following extrusion). } \\
\text { 6. Adult, Resting } \\
\text { Ovaries containing a variety of eggs in different stages } \\
\text { of development. No extremely large eggs present. } \\
\text { Nidamental glands fully developed. No eggs present in } \\
\text { fallopian tubes or oviducts. Oviducts venous and stretched. }\end{array}$ \\
\hline
\end{tabular}

translucent bands (Grade 3) were apparent for the two remaining species, the fact that they never dominated the monthly thornback ray or blonde ray samples is probably due to the difficulties of distinguishing between forming (Grade 2) and fully formed translucent bands (Grade 3), particularly in larger specimens.

For each species no distinct trends in precision among readers were evident indicating each of the readers were equally able to resolve bands (Table 4). The lowest coefficient of variation was evident for reader one's assessment of male thornback ray (0.055) whereas the highest evident was for reader three's readings of female thornback ray (0.154).
ANCOVAs revealed that the differences in the lengthat-age data were only significant between the sexes for the blonde ray (Table 5). There was however a number of distinct trends evident in the derived growth data. Male growth rates were higher than females for each species (Fig. 6-9, Table 6), and a notable divergence in the shape of the growth curves is apparent between the sexes for the thornback ray (Fig. 7). Growth rates were also lower for the two larger sized species, the blonde (male, $K=0.145$; female, $K=0.129$ ) and thornback rays (male, $K=0.135$; female, $K=0.093$ ) compared to the smaller spotted (male, $K=0.304$; female, $K=0.256$ ) and cuckoo (male, $K=$ 0.294 ; female, $K=0.197$ ) rays. However overestimations of $L_{\infty}$ relative to maximum observed sizes were apparent 


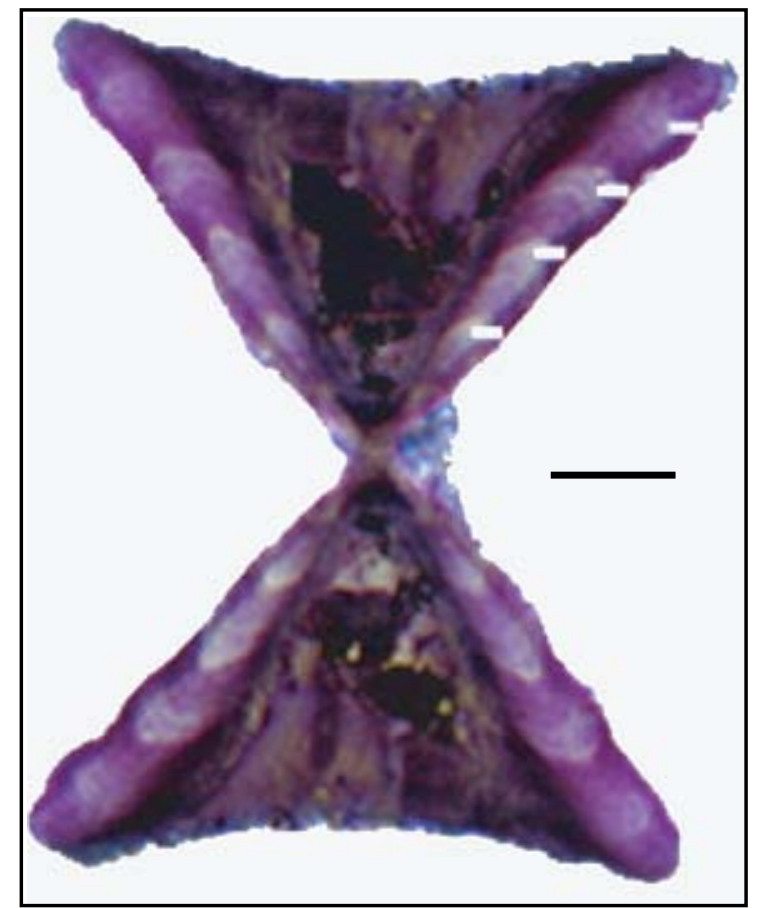

Fig. 1. Photomicrograph of a centrum in longitudinal section, etched in 5\% EDTA and stained in $0.005 \%$ crystal violet, from a spotted ray, Raja montagui, specimen estimated to be in its $5^{\text {th }}$ year. White bars denote the position of enumerated bands. Scale bar $=0.65 \mathrm{~mm}$.

for both larger species (blonde, male $L_{\infty}=145.8$ max. obs. size $=109$ (note: size here in after refers to total length in $\mathrm{cm}$ ), female $L_{\infty}=154.7$ max. obs. size $=108$; (thornback, male $L_{\infty}=106.5$ max. obs. size $=90$, female $L_{\infty}=139.5$ max. obs. size $=104$ ). The limited sample sizes in the larger size-classes for both these species have contributed to an overestimation of length at age resulting in somewhat lower growth rate estimates. The comprehensive sample sizes/ranges evident for both smaller species (Fig. 8 and 9) yielded more comparable maximum observed sizes and $L_{\infty}$ estimates (spotted, male $L_{\infty}=72.4$ max. obs. size $=75$, female $L_{\infty}=78.4$ max. obs. size $=77$; cuckoo, male $L_{\infty}=74.57$ max. obs. size $=71$, female $L_{\infty}=83.92$ max. obs. size $=70$ ).

\section{Maturity}

With the exception of the cuckoo ray (females $=$ 56.16 , males $=56.87$ ) females of all species matured at a larger size than males (Fig. 10 to 17, Table 7). In addition, with the exception of the thornback ray (both sexes 6.13 yrs), all females matured at a later age than males (Fig. 9 to 16 , Table 7). Male spotted ray matured at the earliest age $(3.41 \mathrm{yrs})$ and at the smallest size $(53.65 \mathrm{~cm})$, whilst the thornback ray matured at the latest age $(6.13 \mathrm{yrs}$, both sexes), and the blonde ray at the largest size (females = 83.56 females).

For each species a very gradual increase in the size of claspers in males and nidamental gland width in females relative to body size was evident prior to maturity (Fig. 18-25). However at the onset of maturity (50\% maturity estimates (Table 7) denoted by an arrow) a distinct increase in both clasper size and nidamental gland width was clearly evident for all species examined. For each species the overall shapes of the distributions of clasper size and nidamental gland width relative to increasing body size were similar, and this similarity was particularly evident for both smaller species where sample sizes were larger (Fig. 22-25).

\section{Discussion}

The modification of the crystal violet staining technique initially investigated by Schwartz (1983) proved very effective. Owing to the simplicity and versatility of the single-stage staining process the desired stain intensity could readily be ascertained and over-stained sections could be de-stained effectively using alcohol. Preliminary trials using this technique also showed potential for a variety of other elasmobranch species (common skate; Raja batis, shagreen ray; R. fullonica, Arctic skate; $R$. hyperborea, small eyed ray; $R$. microocellata, long nosed skate; $R$. oxyrhincus, Norwegian skate; $R$. nidarosiensis, Richardson's ray; Bathyraja richardsoni, blue shark; Prionace glauca, lesser spotted dogfish; Scyliorhinus canicula, greater spotted dogfish; $S$. stellaris and the blackmouth catshark; Galeus melastomus).

The temporal range of samples examined allowed both the rate and timing of band formation to be derived using centrum edge analysis. For each species, annual band pair formation, and in addition, opaque band formation associated with the summer-autumn growth phase was evident. This confirms Holden and Vince's (1973) observation on the rate and timing of band formation for the thornback ray in the southern North Sea, and compares with band formation processes for several other elasmobranch species (Brandstetter, 1987; Martin and Cailliet, 1988; Zeiner and Wolf, 1993).

Growth and maturity estimates revealed that the larger rays (blonde and thornback rays) reached maturity at larger sizes and later ages, and displayed slower growth than both smaller rays (spotted and cuckoo rays). Overall, growth estimates agreed most closely with those 


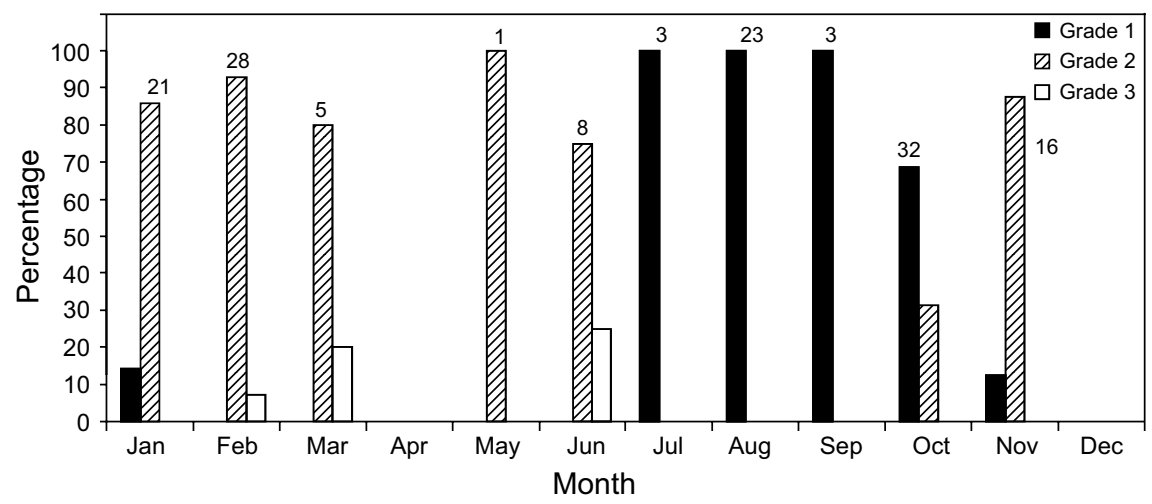

Fig. 2. Temporal characteristics in the growing edge of centrum sagittal sections, from R. brachyura, using a grading system defined by Yudin and Cailliet (1990). Columns indicate percent frequency of each grade, with associated numbers denoting monthly totals examined.

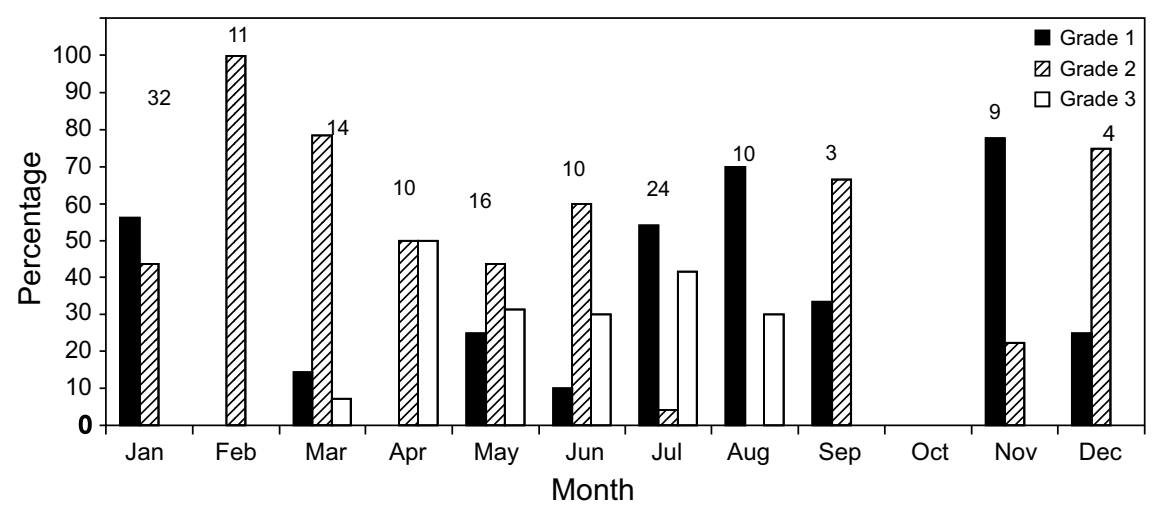

Fig .3. Temporal characteristics in the growing edge of centrum sagittal sections, from $R$. clavata, using a grading system defined by Yudin and Cailliet (1990). Columns indicate percent frequency of each grade, with associated numbers denoting monthly totals examined.

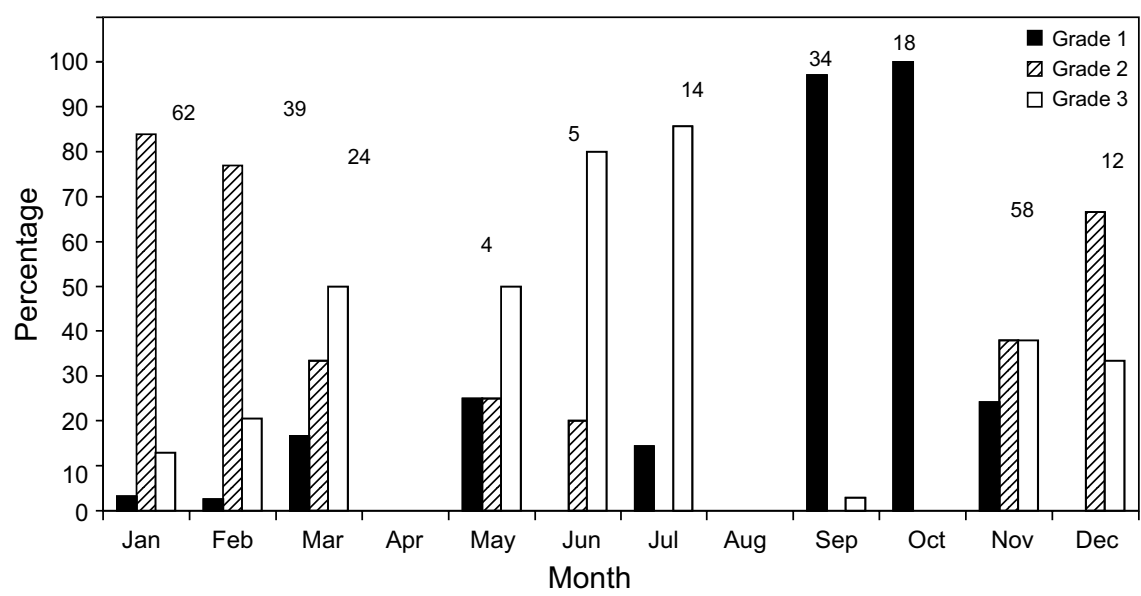

Fig. 4. Temporal characteristics in the growing edge of centrum sagittal sections, from R. montagui, using a grading system defined by Yudin and Cailliet (1990). Columns indicate percent frequency of each grade, with associated numbers denoting monthly totals examined. 


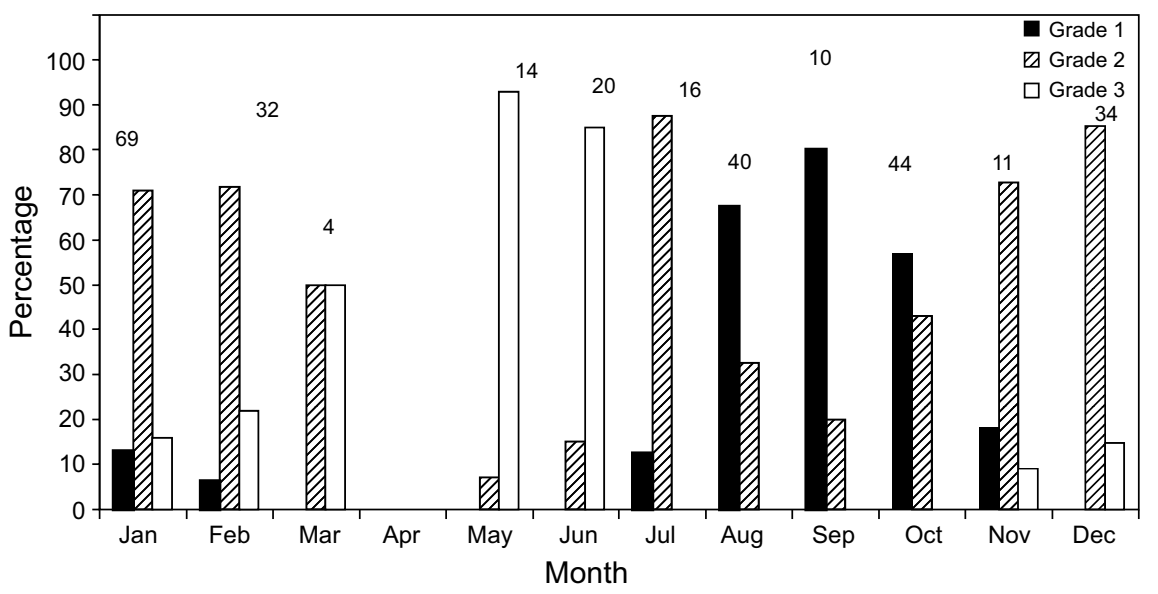

Fig. 5. Temporal characteristics in the growing edge of centrum sagittal sections, from $R$. naevus, using a grading system defined by Yudin and Cailliet (1990). Columns indicate percent frequency of each grade, with associated numbers denoting monthly totals examined.

TABLE 4. Chang's (1982) coefficient of variation $(V)$ and mean reader precision $(D)$ for sagittal section band counts made by three readers for $R$. brachyura, $R$. clavata, $R$. montagui, and $R$. naevus. $n=$ sample size.

\begin{tabular}{|c|c|c|c|c|c|c|c|c|}
\hline \multirow[t]{2}{*}{ Species } & \multirow[t]{2}{*}{ Structure } & \multirow[b]{2}{*}{$n$} & \multicolumn{2}{|c|}{ Reader 1} & \multicolumn{2}{|c|}{ Reader 2} & \multicolumn{2}{|c|}{ Reader 3} \\
\hline & & & $V$ & $D$ & $V$ & $D$ & $V$ & $D$ \\
\hline \multirow[t]{2}{*}{ R.brachyura } & Male & 30 & 0.079 & 0.045 & 0.087 & 0.050 & 0.072 & 0.042 \\
\hline & Female & 30 & 0.096 & 0.055 & 0.096 & 0.055 & 0.072 & 0.042 \\
\hline \multirow[t]{2}{*}{ R. clavata } & Male & 30 & 0.055 & 0.032 & 0.112 & 0.065 & 0.154 & 0.089 \\
\hline & Female & 30 & 0.059 & 0.034 & 0.087 & 0.050 & 0.081 & 0.047 \\
\hline \multirow[t]{2}{*}{ R.montagui } & Male & 30 & 0.117 & 0.068 & 0.099 & 0.057 & 0.068 & 0.039 \\
\hline & Female & 30 & 0.088 & 0.051 & 0.094 & 0.054 & 0.073 & 0.042 \\
\hline \multirow[t]{2}{*}{ R.naevus } & Male & 30 & 0.083 & 0.048 & 0.143 & 0.083 & 0.145 & 0.083 \\
\hline & Female & 30 & 0.116 & 0.067 & 0.118 & 0.068 & 0.103 & 0.060 \\
\hline
\end{tabular}

TABLE 5. Analysis of covariance, testing for difference in length at age between the sexes of Raja brachyura, $R$. clavata, $R$. montagui and $R$. naevus. Ages based on sagittal section band counts. $n=$ sample size.

\begin{tabular}{lccc}
\hline \hline & $n$ & $F$ ratio & $P$ value \\
\hline R. brachyura & 127 & 7.704 & 0.006 \\
R. clavata & 93 & 1.072 & 0.302 \\
R. montagui & 194 & 2.057 & 0.152 \\
R. naevus & 209 & 2.537 & 0.112 \\
\hline
\end{tabular}

of Fahy (1991), which are the most recent and geographically relevant estimates relative to this study (Table 1). Overestimations of $L_{\infty}$ relative to maximum observed sizes was evident in this study for both the blonde and thornback rays and is largely due to the dearth of samples in the larger size-classes. In fact Fahy's $(1989,1991) L_{\infty}$ estimates for both species were in closer agreement to the maximum observed sizes derived in this particular 


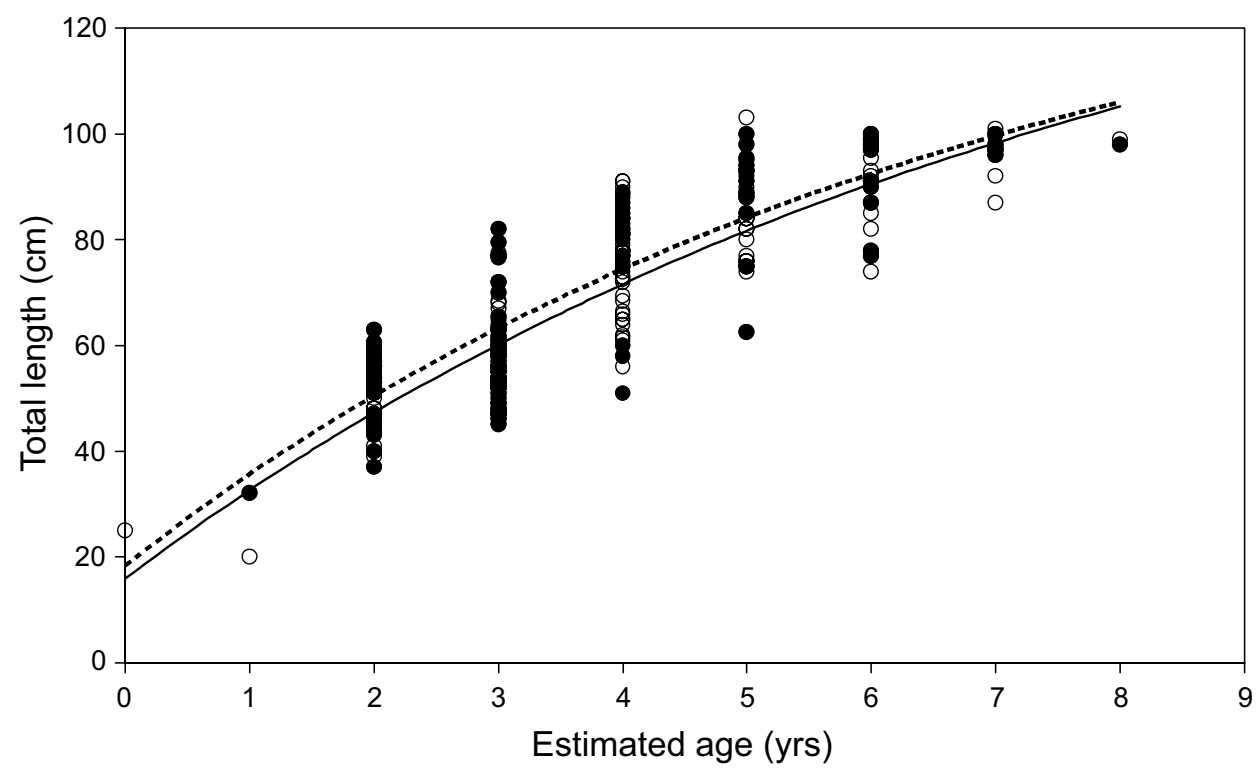

Fig. 6. Observed length-at-age data for Raja brachyura, by sex, with predicted von Bertalanffy growth curves fitted using Fishparm (Prager et al., 1987). Ages based on sagittal section band counts.

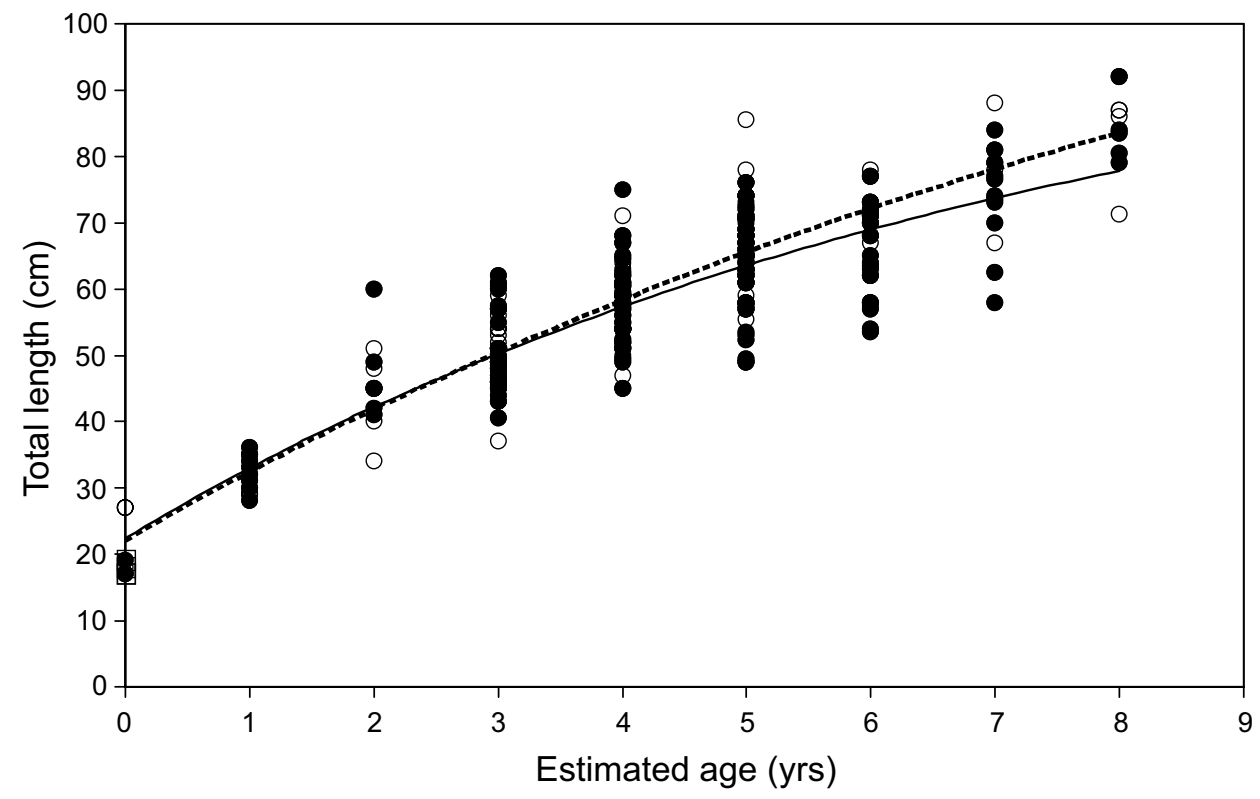

Fig. 7. Observed length-at-age data for Raja clavata, by sex, with predicted von Bertalanffy growth curves fitted using Fishparm (Prager et al., 1987). Ages based on sagittal section band counts.

study, possibly suggesting more realistic growth for both species. However an examination of Fahy's (1991) data reveals an overestimation of length at age in the smaller size-classes and widely varying $t_{0}$ estimates. This may be due to the fact that Fahy $(1989,1991)$ used whole centra for age estimation purposes and further highlights the fact that poor resolution of growth increments near the nucleus of whole centra is a recognised problem in Irish Sea ray species (Taylor and Holden, 1964; Brander and Palmer, 1985). 


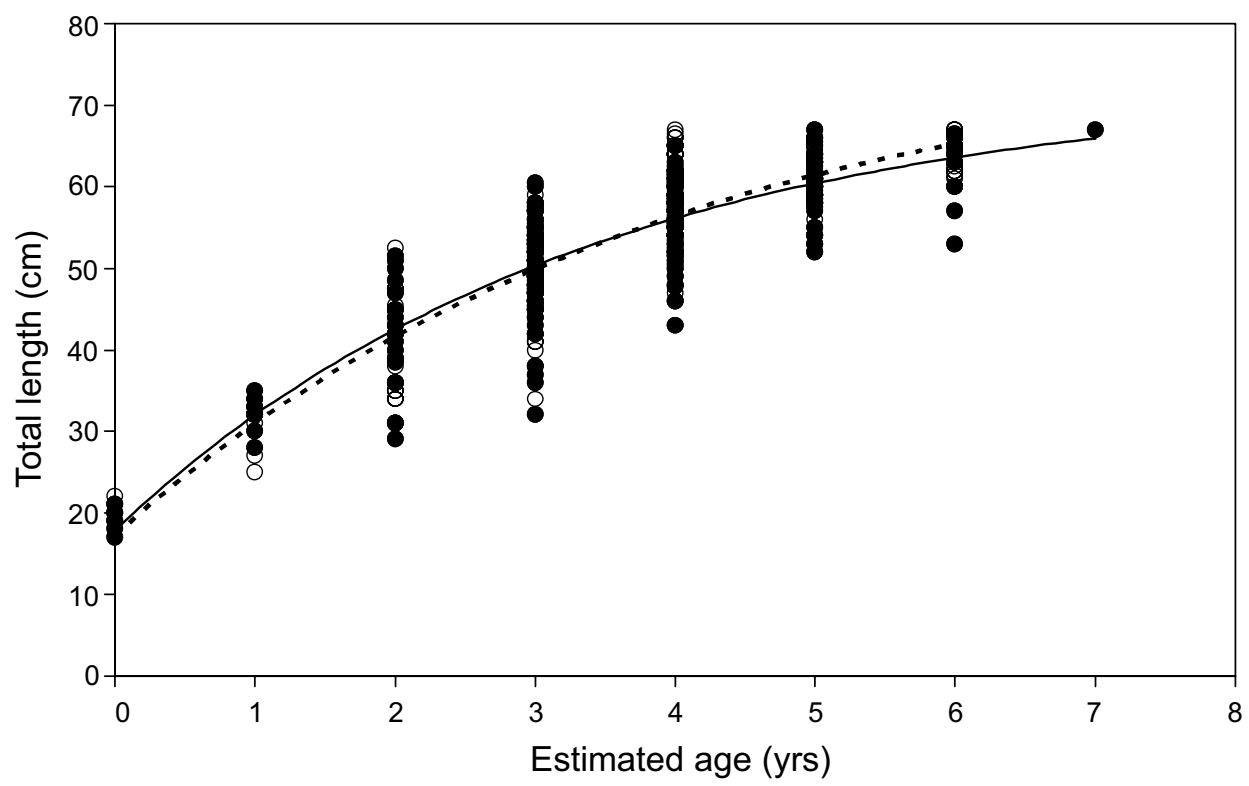

Fig. 8. Observed length-at-age data for Raja montagui, by sex, with predicted von Bertalanffy growth curves fitted using Fishparm (Prager et al., 1987). Ages based on sagittal section band counts.

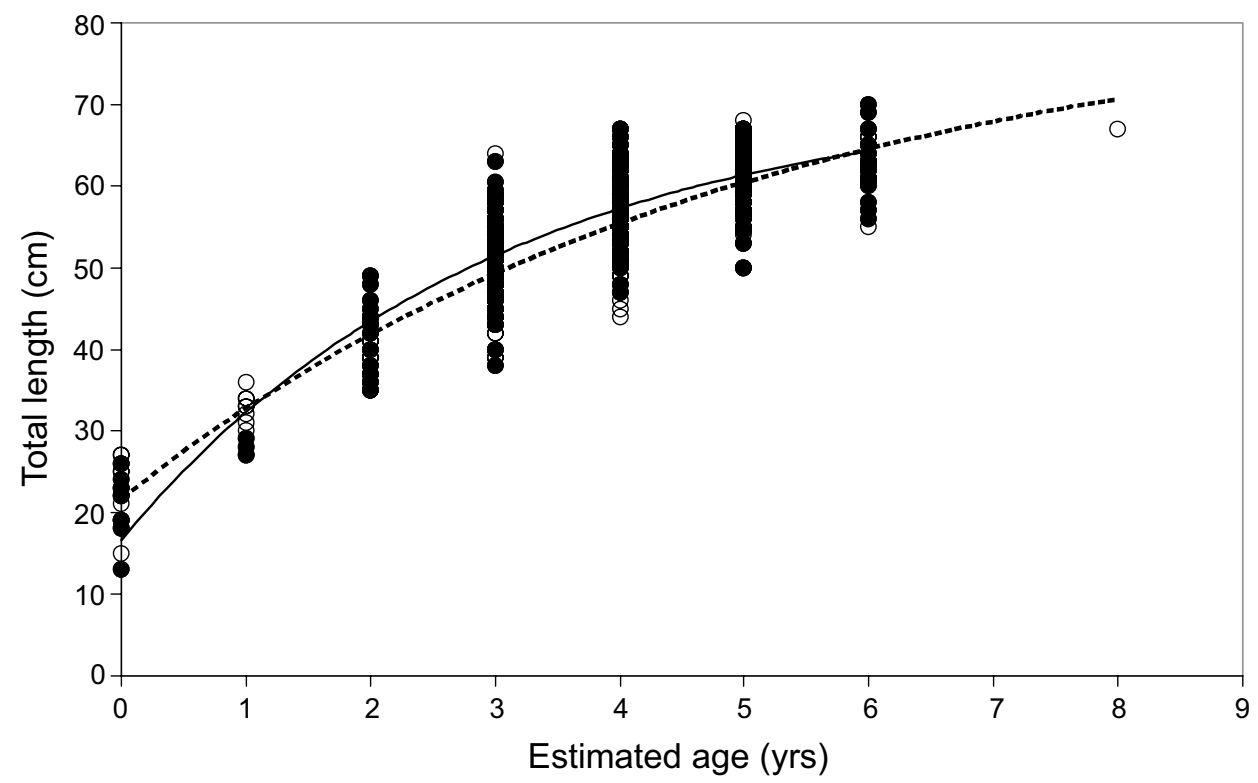

Fig. 9. Observed length-at-age data for Raja naevus, by sex, with predicted von Bertalanffy growth curves fitted using Fishparm (Prager et al., 1987). Ages based on sagittal section band counts

Growth estimates for the spotted and cuckoo rays appeared more robust in this study, owing to comprehensive sample sizes, and $L_{\infty}$ and maximum observed sizes are also in close agreement in each species.
The results for the spotted and cuckoo rays were also in very close agreement with those of Fahy (1989). It is interesting to note that although there was close agreement between the growth estimates between both Fahy's (1989, 
TABLE 6. von Bertalanffy growth parameters of $L_{\infty}=$ theoretical maximum length (total length $(\mathrm{cm})$ ), $K=$ Brody growth coefficient, $t_{0}=$ theoretical age at which length is zero, based on sagittal section band counts, with standard error of each parameter given in parentheses and maximum observed sizes (max. obs. size) (total length $(\mathrm{cm})$ ) based on field observations for Raja brachyura, $R$. clavata, $R$. montagui, $R$. naevus. $n=$ sample size.

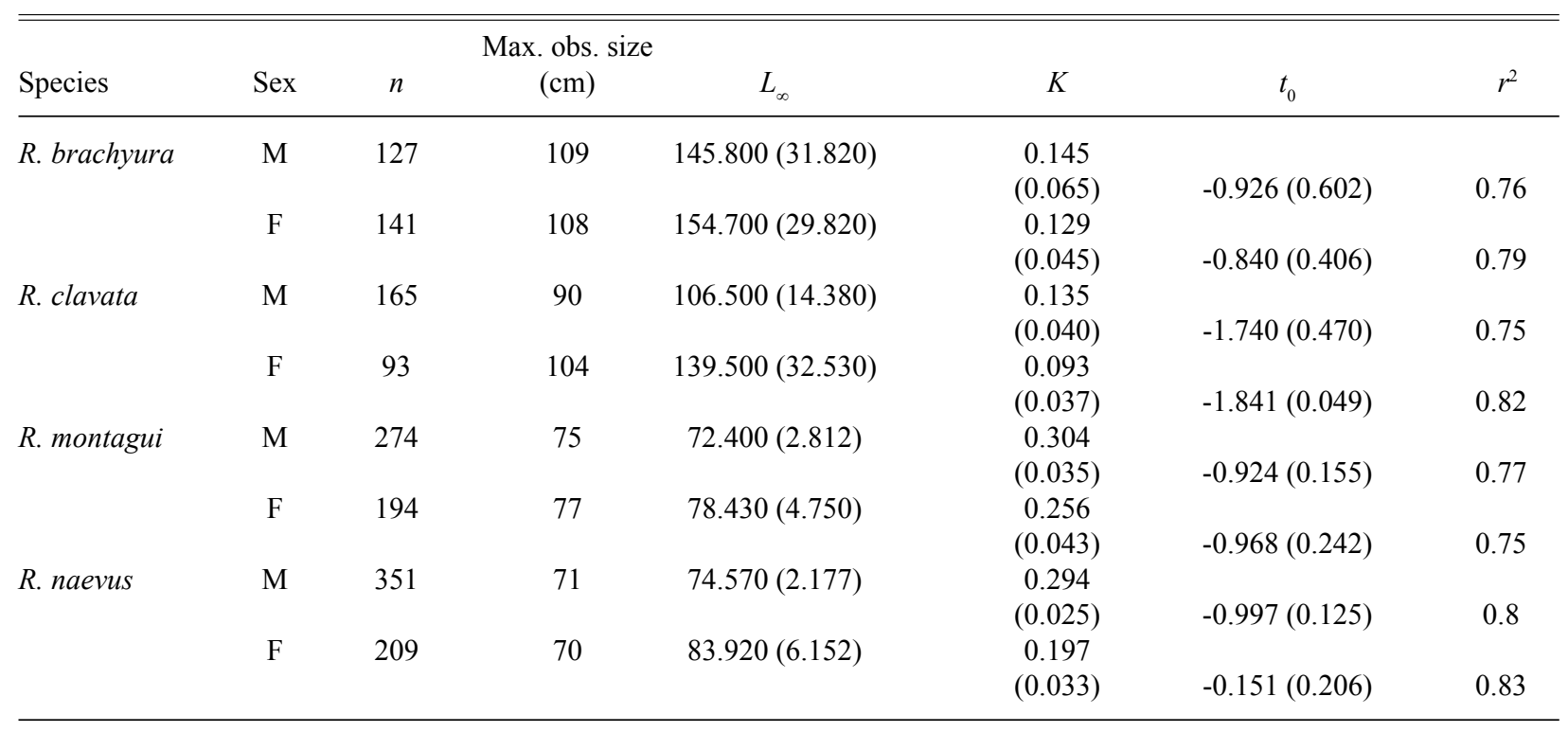

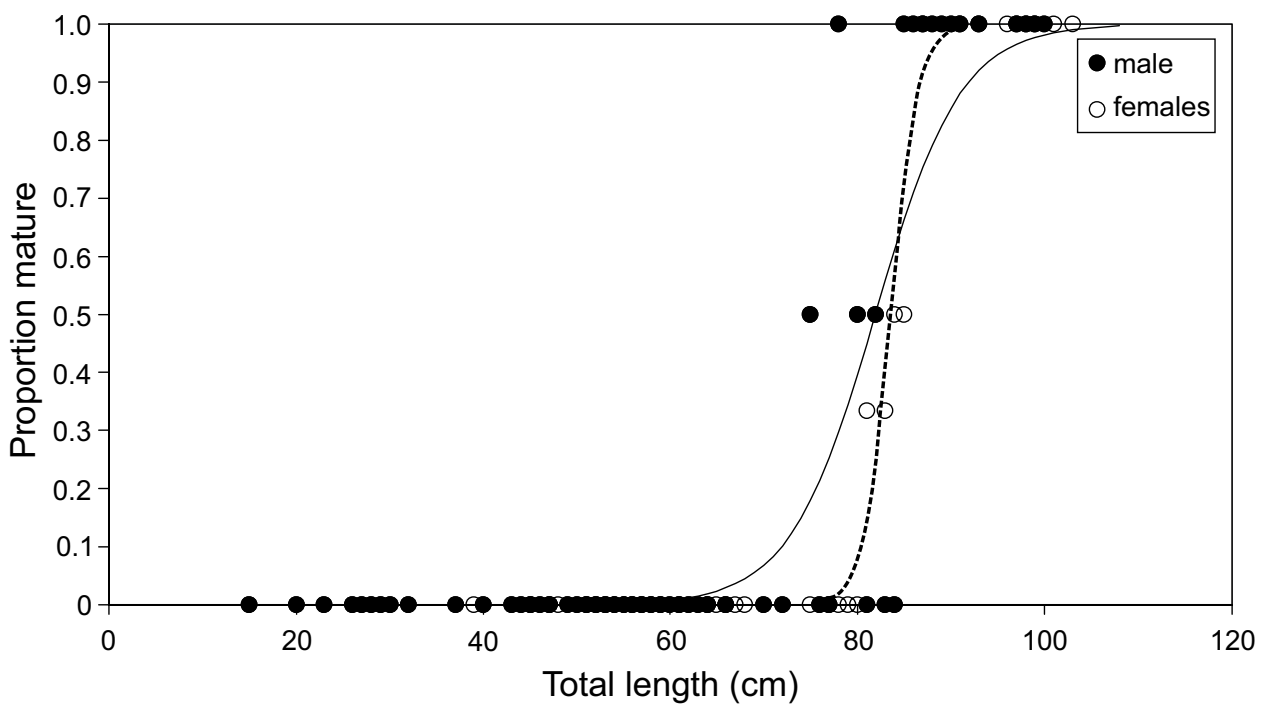

Fig. 10. Ogive of size (total length $(\mathrm{cm})$ ) at maturity for R. brachyura, by sex.

1991) and this study increases in the growth rates of these two species are suggested compared to previous studies (Holden, 1972; Ryland and Ajayi, 1984).

Despite the almost certain variability in maturity estimates between studies owing to differing maturity assessment methods, the results for the thornback ray in this and other studies (Williams et al., 1965; Nottage and Perkins, 1983; Ryland and Ajayi, 1984) suggest that both size- and age-at-maturity has decreased over the long term (Steven, 1936). One of the more recent studies of commercial ray species in the eastern Irish Sea (Ryland and Ajayi, 1984) reported both lower size- and age-atmaturity estimates for the thornback ray than this study, 


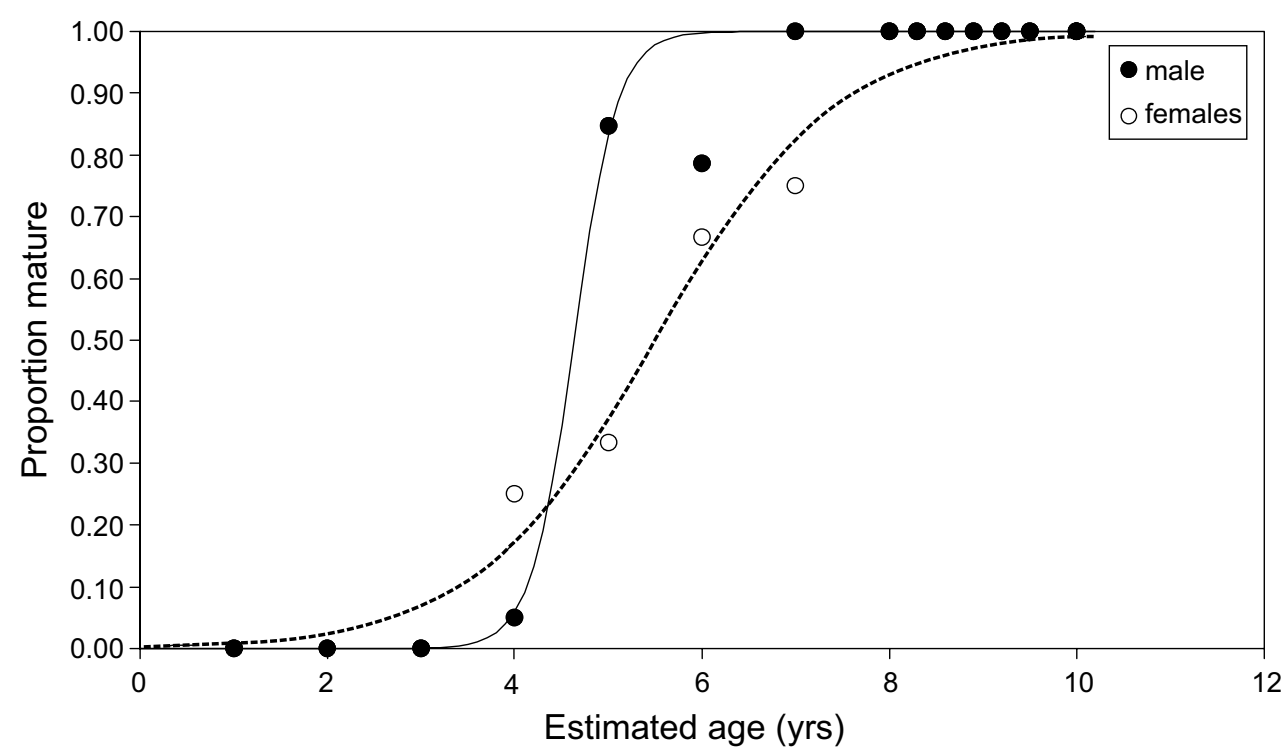

Fig. 11. Ogive of age (yrs) at maturity for R. brachyura, by sex. Ages based on sagittal section band counts.

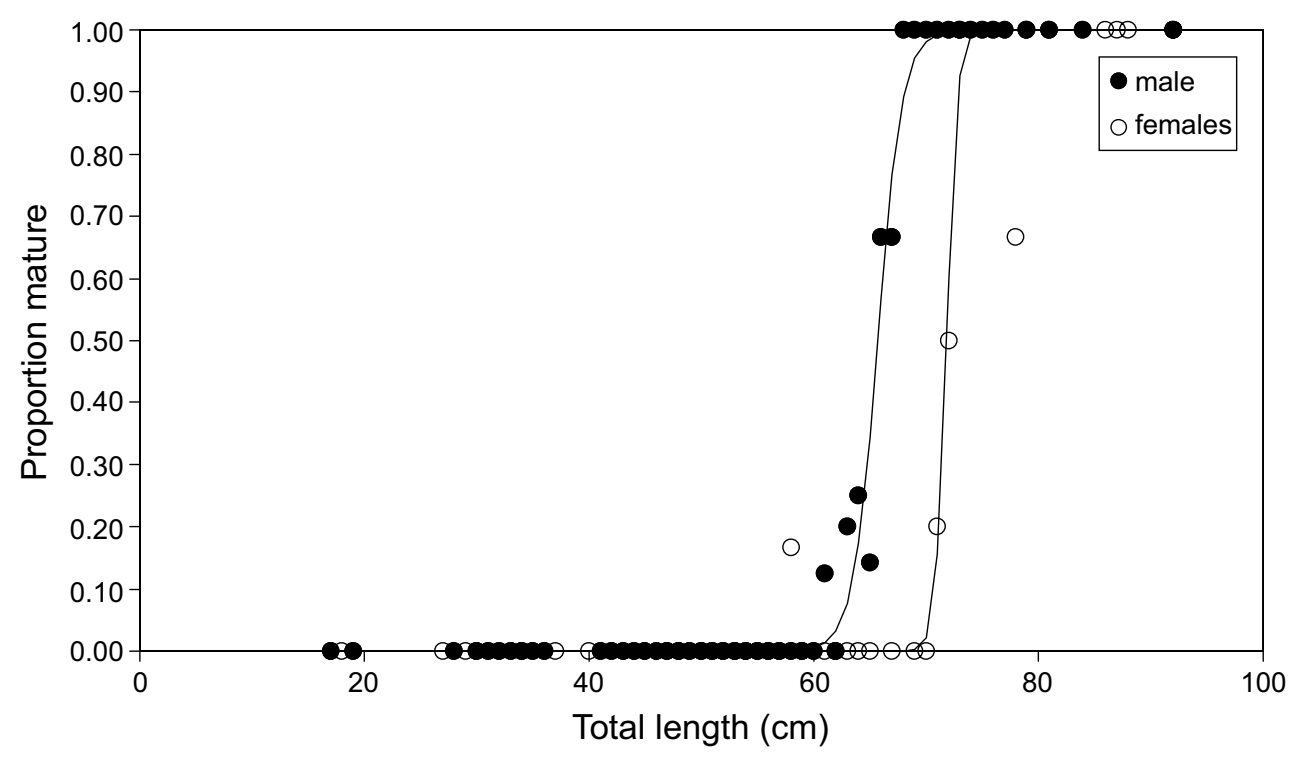

Fig. 12. Ogive of size (total length (cm)) at maturity for $R$. clavata, by sex.

which is to be expected to some extent as first maturity was quoted, whereas $50 \%$ maturity was estimated in this study. However when maturity estimates for the spotted ray are compared between both studies, the same trend is not evident, with both lower age and smaller size-atmaturity evident in this study. This would suggest that in addition to increases in the growth rate, reductions in both the size- and age-at-maturity have occurred for the spotted ray recently. Although no previous maturity estimates are available for the cuckoo ray in the Irish Sea it is probable that similar changes in growth and maturity have also occurred for this species.

The affects of long-term exploitation on life history traits through changes in stock structures and relative abundances have also been suggested for a number of other ray fisheries (Anon, 1999b; Agnew et al., 2000; Kulka and Miri, MS 2003). For the Irish Sea it is apparent that historical levels of fishing mortality were too high to sustain the slow growing $(K=0.060)$ and late 


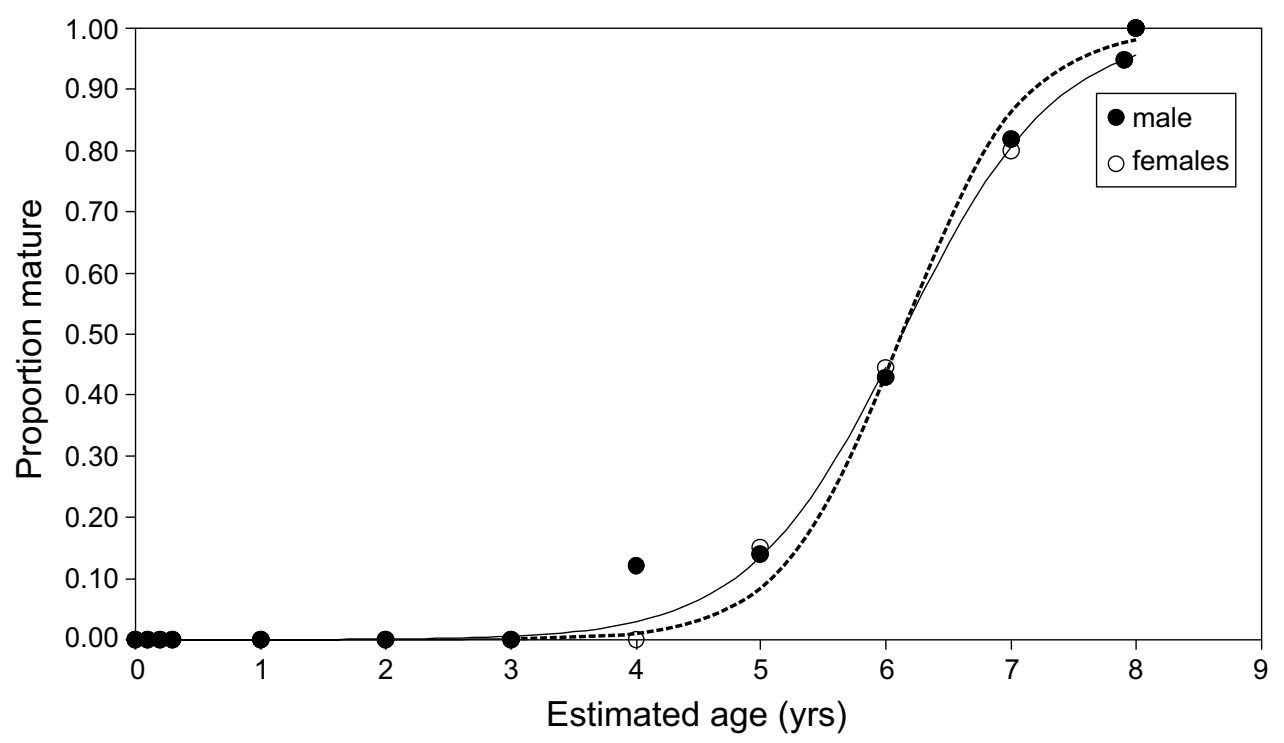

Fig. 13. Ogive of age-at-maturity (yrs) for R. clavata, by sex. Ages based on sagittal band counts.

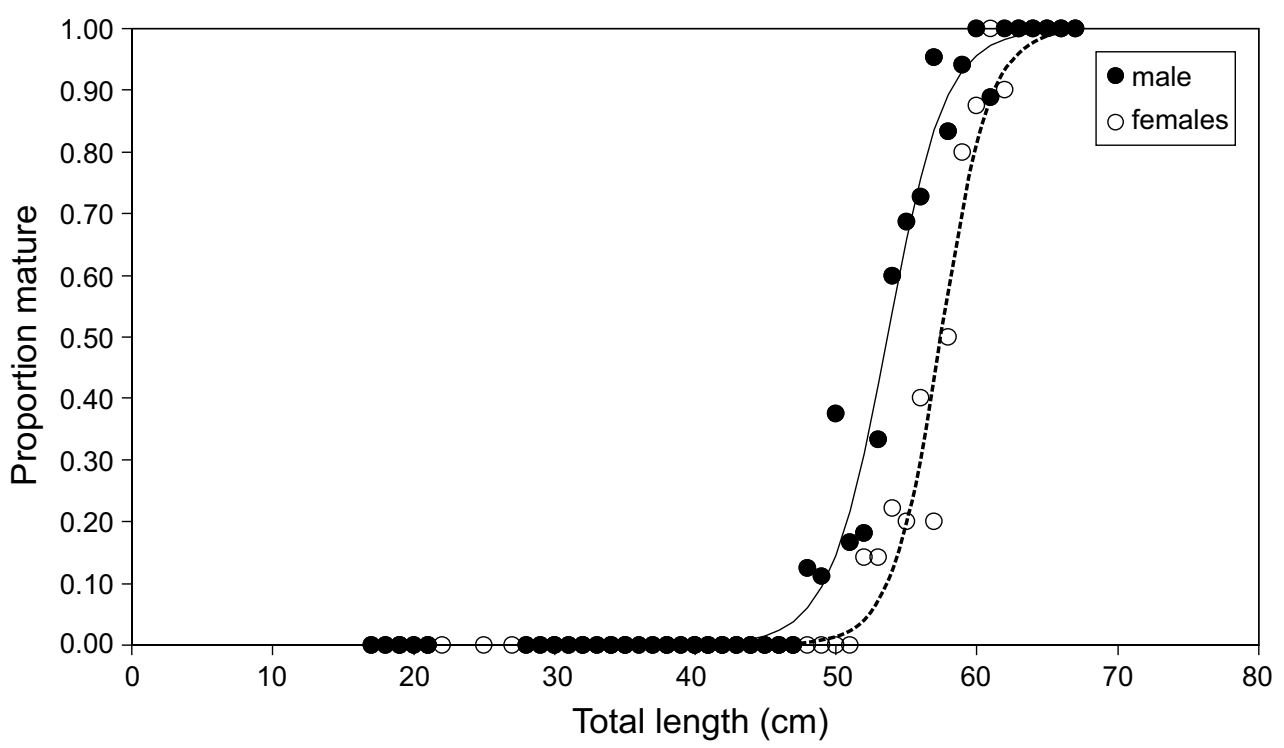

Fig. 14. Ogive of size (total length $(\mathrm{cm})$ ) at maturity for R. montagui, by sex.

maturing (11 yrs) common skate ( $R$. batis), which was commercially extirpated in the 1970s (Brander, 1981). In addition, although aggregated landings and catch statistics suggested relative stability in the Irish Sea ray fishery, examination of species-specific trawl survey data over a 60 -year period indicated that the slower growing and later maturing thornback ray dropped in abundance (Dulvy et al., 2000). In addition to changes in population density the size structure of the stock has also changed for the thornback ray, with few specimens reported above $90 \mathrm{~cm}$ total length over recent decades (Holden, 1977;
Fahy, 1989; Gallagher, 2000), whereas specimens above $100 \mathrm{~cm}$ were commonplace in the earlier part of the last century (Steven, 1936). These changes effected possible reductions in age- and size-at-maturity of this species (Steven, 1936; Williams et al., 1965; Nottage and Perkins, 1983; Ryland and Ajayi, 1984; Gallagher, 2000) but were not sufficient to prevent a reduction in abundance (Fahy, 1989; Dulvy et al., 2000; Gallagher, 2000).

Increases in abundance have recently been noted for the cuckoo ray in the western Irish Sea from commercial 


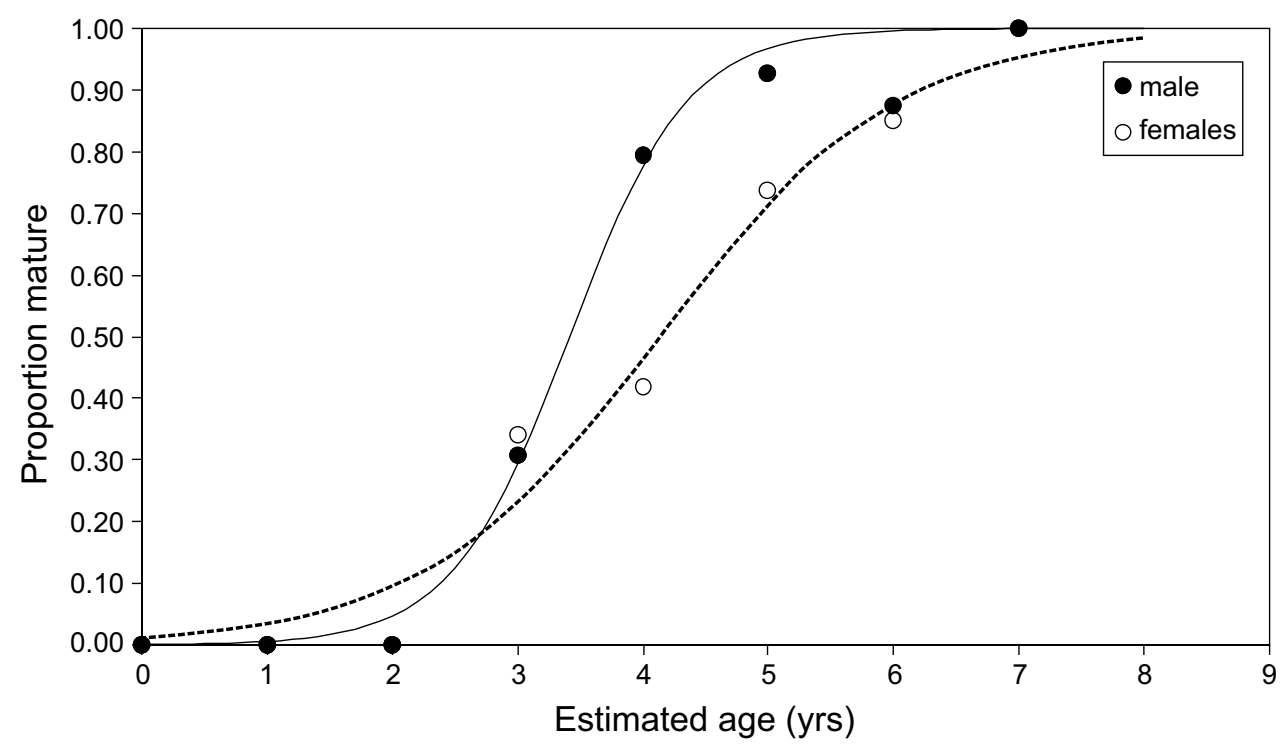

Fig. 15. Ogive of age (yrs) at maturity for R. montagui, by sex.

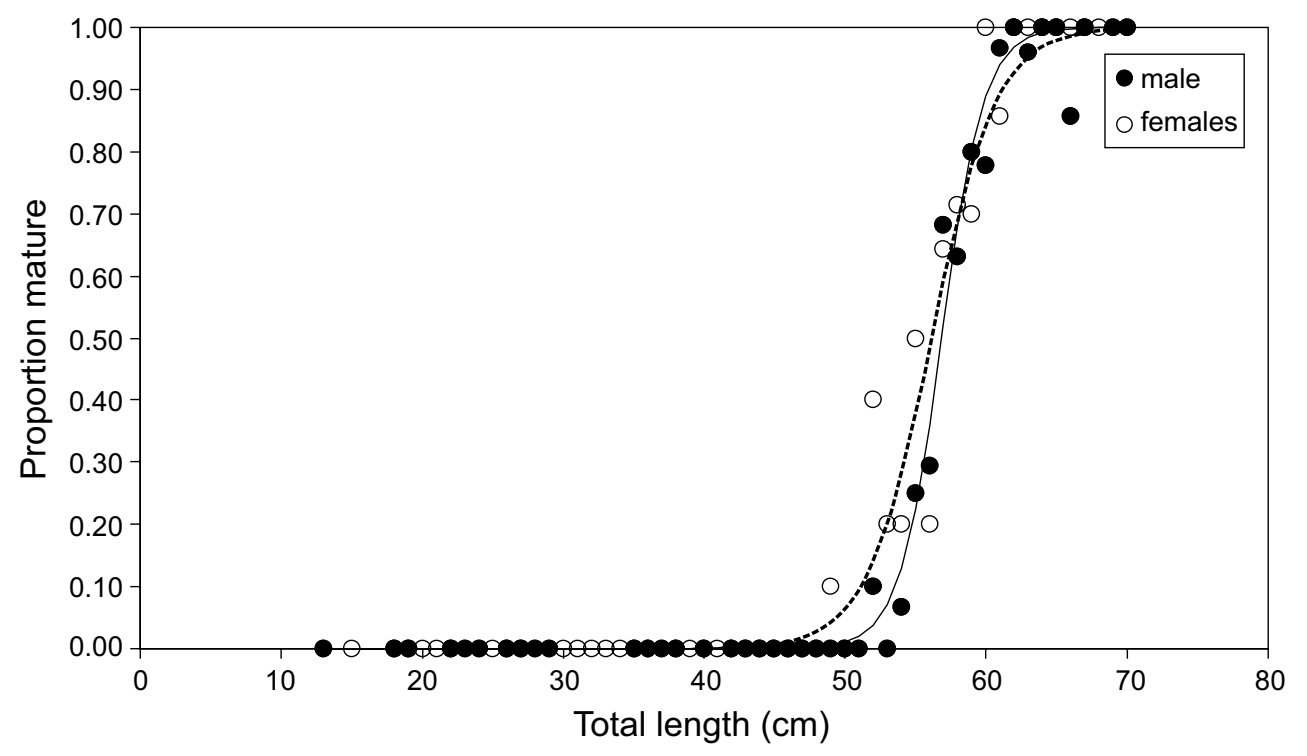

Fig. 16. Ogive of size (total length $(\mathrm{cm})$ ) at maturity for R. naevus, by sex.

landings (Fahy, 1989, Gallagher, 2000) and for both the cuckoo and spotted rays in the eastern Irish Sea from longterm trawl survey data (Dulvy et al., 2000). Dulvy et al. (2000) suggested that these increases in abundances are a result of additional food availability due to the decline in abundance of the larger sized species. However it is equally likely that the compensatory changes in life history traits (growth and maturity) of these less $k$-selected species have resulted in the increases in abundance. A similar phenomenon was also noted in the North Sea (Walker and Hislop, 1998), and was also attributed to the changes in life history traits of the rapid growing early maturing starry ray, $R$. radiata.

Other factors also influence the sustainability of a species. Protection of the reproductive potential of a stock is important, particularly in elasmobranchs, given the close stock/recruitment relationship (Holden, 1974; Anderson, 1990). The blonde ray, the largest and most commercially important species, has sustained almost a century of directed effort (Steven, 1936; Gallagher, 2000). However despite the fact that this species is slower 


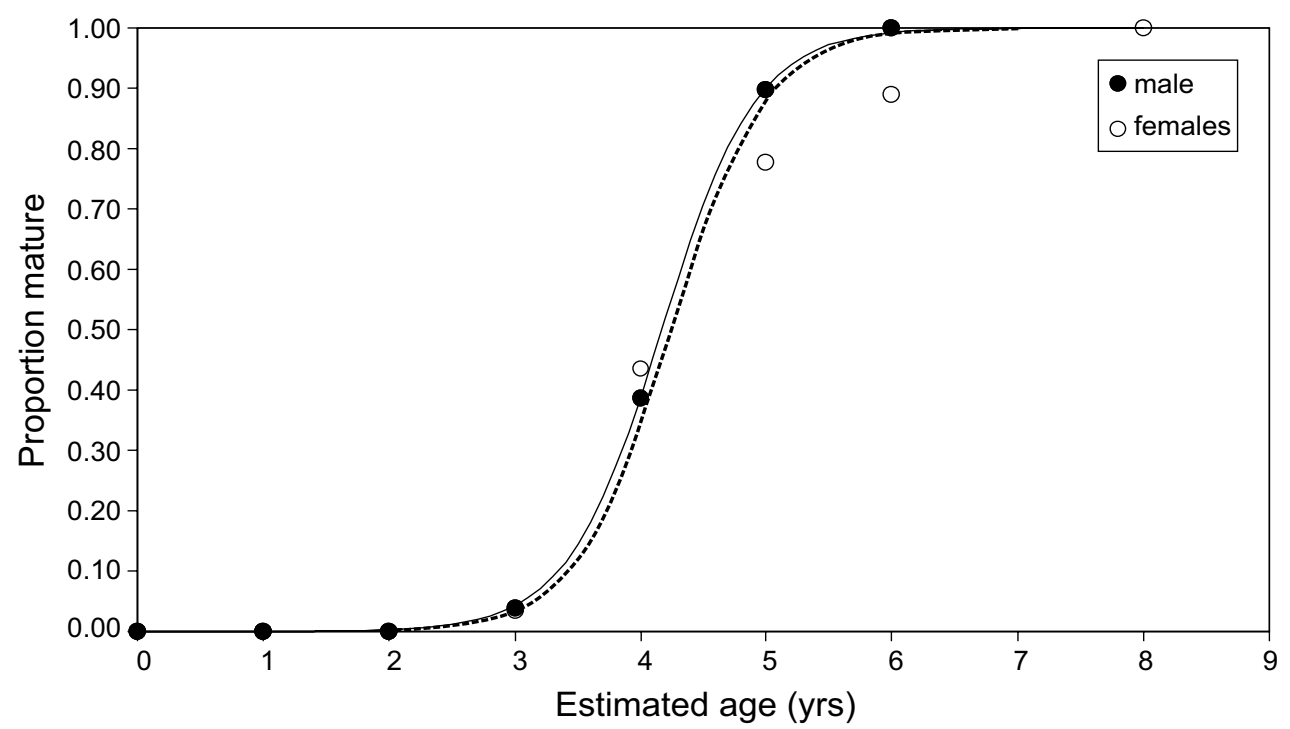

Fig. 17. Ogive of age (yrs) at maturity for R. naevus, by sex.

TABLE 7. Total length (TL (cm)) and age (yrs) at 50\% maturity for Irish Sea ray species, by sex, based on the logistic model (Fishparm Prager et al., 1987). Figures in parentheses denote standard error values for maturity estimate. Ages based on sagittal section band counts. $n=$ sample size.

\begin{tabular}{|c|c|c|c|c|c|c|}
\hline Species & Sex & $n$ & $\mathrm{TL}$ at $50 \%$ maturity & $r^{2}$ & Age at $50 \%$ maturity & $r^{2}$ \\
\hline \multirow[t]{2}{*}{ R. brachyura } & $\mathrm{M}$ & 123 & $81.92 \quad(1.063)$ & 0.77 & $4.63 \quad(0.155)$ & 0.96 \\
\hline & $\mathrm{F}$ & 61 & $83.56(0.154)$ & 0.99 & $5.504 \quad(1.155)$ & 0.97 \\
\hline \multirow[t]{2}{*}{ R. clavata } & M & 165 & $65.7 \quad(0.218)$ & 0.96 & $6.13(0.076)$ & 0.99 \\
\hline & $\mathrm{F}$ & 90 & $71.809 \quad(0.107)$ & 0.97 & $6.13 \quad(0.039)$ & 1 \\
\hline \multirow[t]{2}{*}{ R. montagui } & M & 274 & $53.65(0.185)$ & 0.98 & $3.41 \quad(0.095)$ & 0.98 \\
\hline & $\mathrm{F}$ & 175 & $57.44 \quad(0.189)$ & 0.98 & $4.135(0.172)$ & 0.95 \\
\hline \multirow[t]{2}{*}{ R. naevus } & M & 353 & $56.87 \quad(0.132)$ & 0.99 & $4.17 \quad(0.006)$ & 1 \\
\hline & $\mathrm{F}$ & 191 & $56.16 \quad(0.266)$ & 0.97 & $4.25 \quad(0.076)$ & 0.99 \\
\hline
\end{tabular}

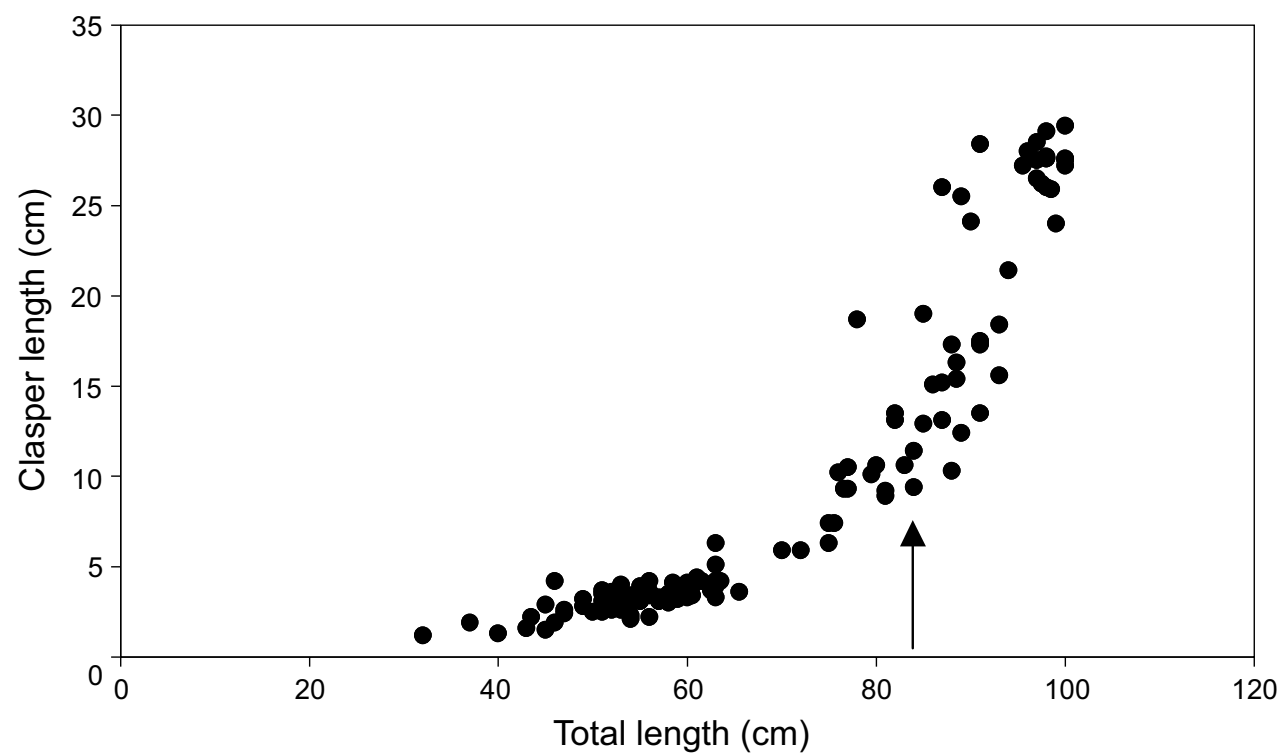

Fig. 18. Relationship between clasper length $(\mathrm{cm})$ and total length $(\mathrm{cm})$ for $R$. brachyura. Arrow on $\mathrm{X}$-axis denotes $50 \%$ maturity. 


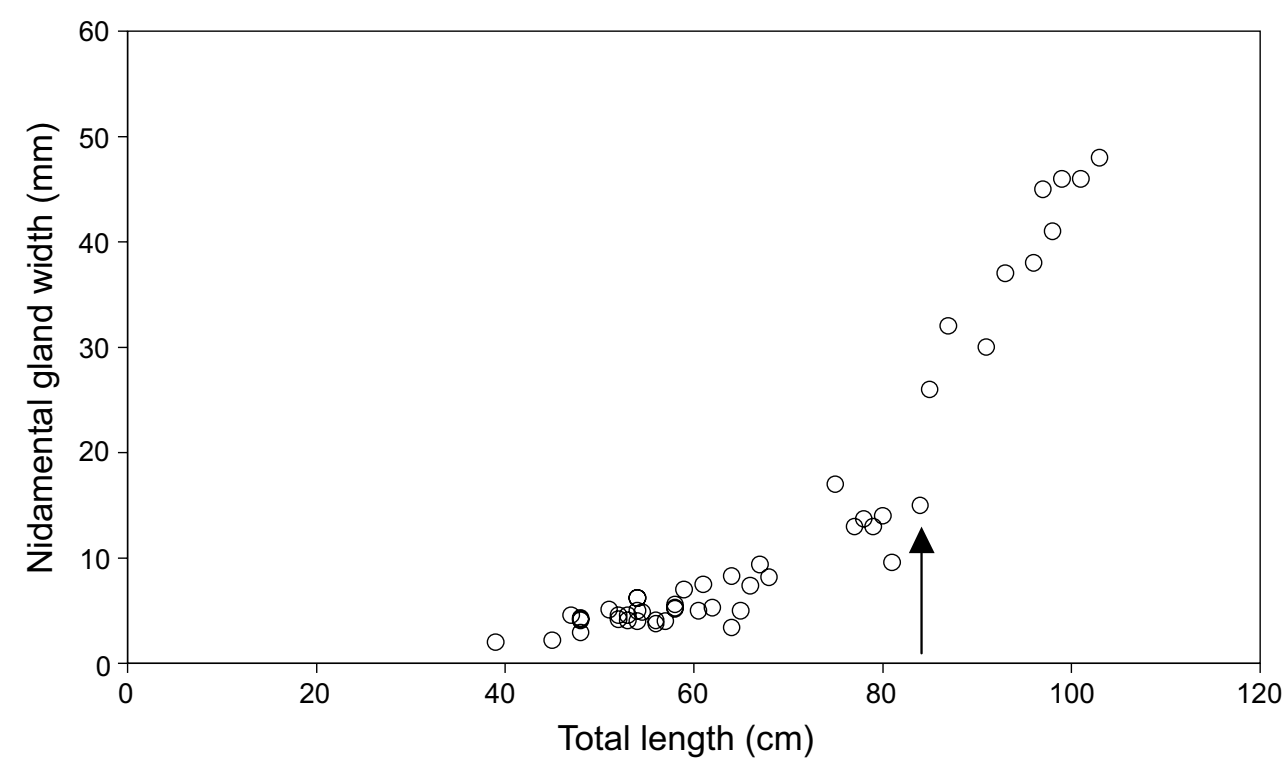

Fig. 19. Relationship between nidamental gland width ( $\mathrm{mm})$ and total length $(\mathrm{cm})$ for $R$. brachyura. Arrow on $\mathrm{X}$-axis denotes $50 \%$ maturity.

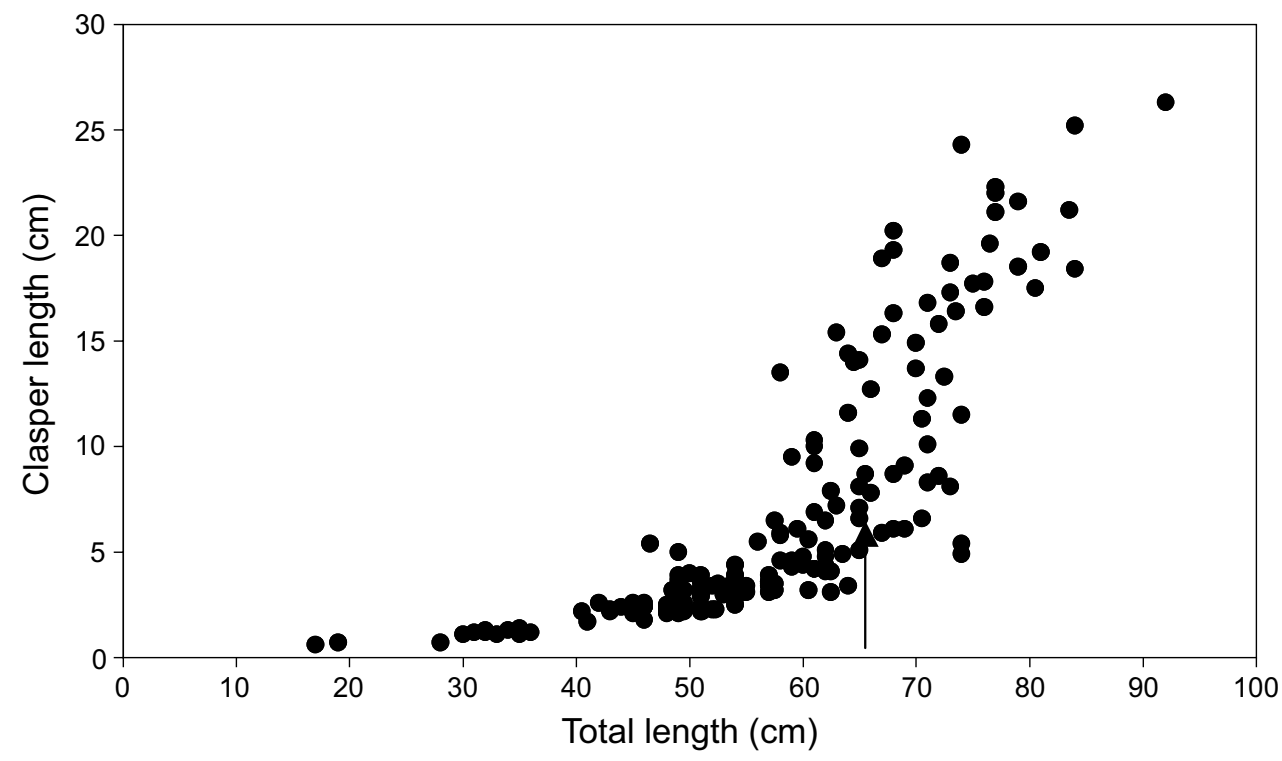

Fig. 20. Relationship between clasper length $(\mathrm{cm})$ and total length $(\mathrm{cm})$ for $R$. clavata. Arrow on X-axis denotes $50 \%$ maturity.

growing, matures at a later age and larger size than the smaller sized spotted and cuckoo rays, numbers have not diminished substantially (Gallagher, 2000). It has been suggested that a higher proportion of females of this species remain in inshore nursery grounds and therefore are not vulnerable to the directed fishery (Gallagher, 2000).
The Irish Sea is a heavily exploited environment that has yielded consistent aggregated catches of rays for almost a century (Steven, 1936; Pawson and Vince, 1999; Gallagher, 2000); however, it is clear that under these conditions only the species with the appropriate life history traits and the capacity to respond to changes 


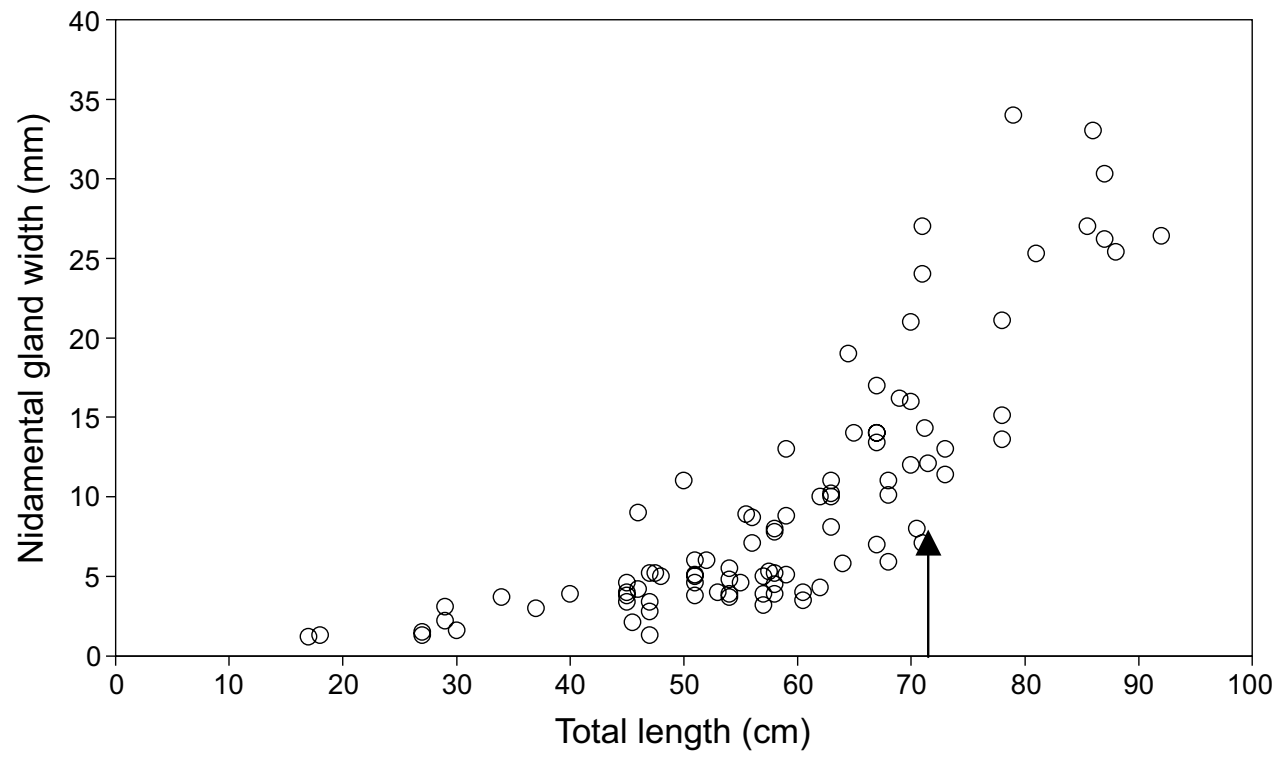

Fig. 21. Relationship between nidamental gland width $(\mathrm{mm})$ and total length $(\mathrm{cm})$ for $R$. clavata. Arrow on $\mathrm{X}$-axis denotes $50 \%$ maturity.

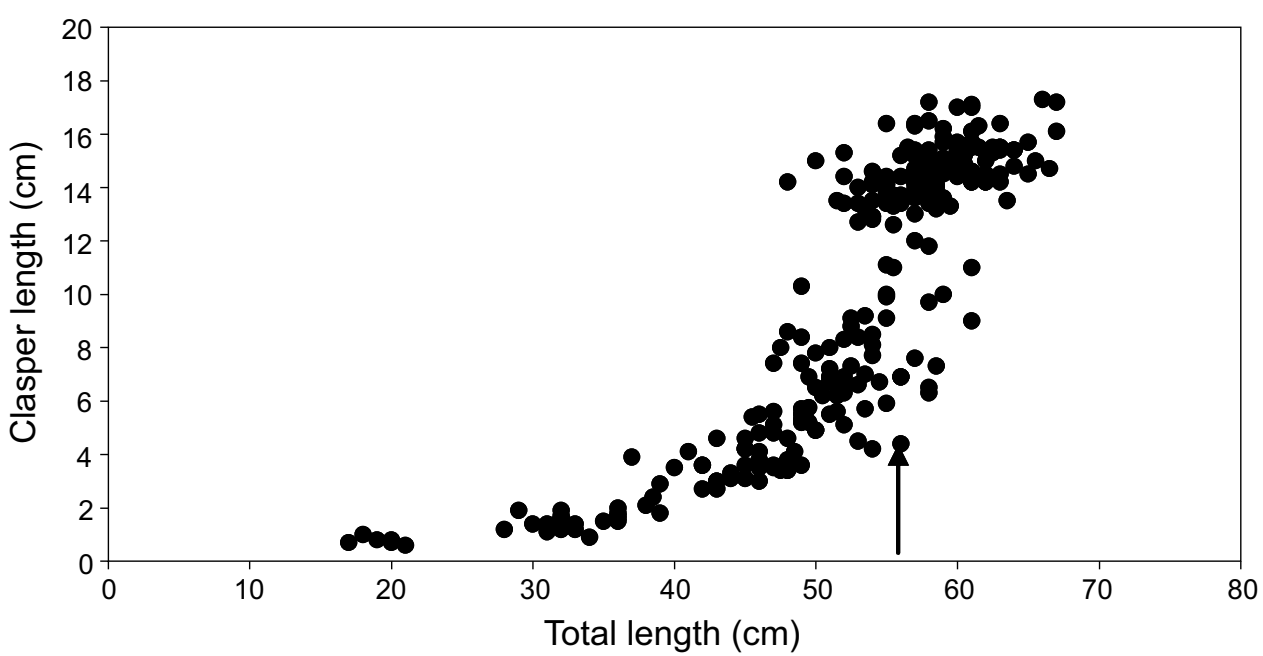

Fig. 22. Relationship between clasper length $(\mathrm{cm})$ and total length $(\mathrm{cm})$ for $R$. montagui. Arrow on $\mathrm{X}$-axis denotes $50 \%$ maturity.

in fishing pressures will flourish. Further work is warranted in this area especially on the collection of more detailed time series fisheries independent trawl survey data to fully verify if these suggested changes have occurred. In addition comparisons of growth and maturity characteristics of heavily fished and relatively un-fished sub-populations of each species is also required to verify if differing pressures are exerting proportionate changes in life history traits. It is also important that the same growth and maturity techniques are used for each study to minimize the confounding variations resulting from different techniques. 


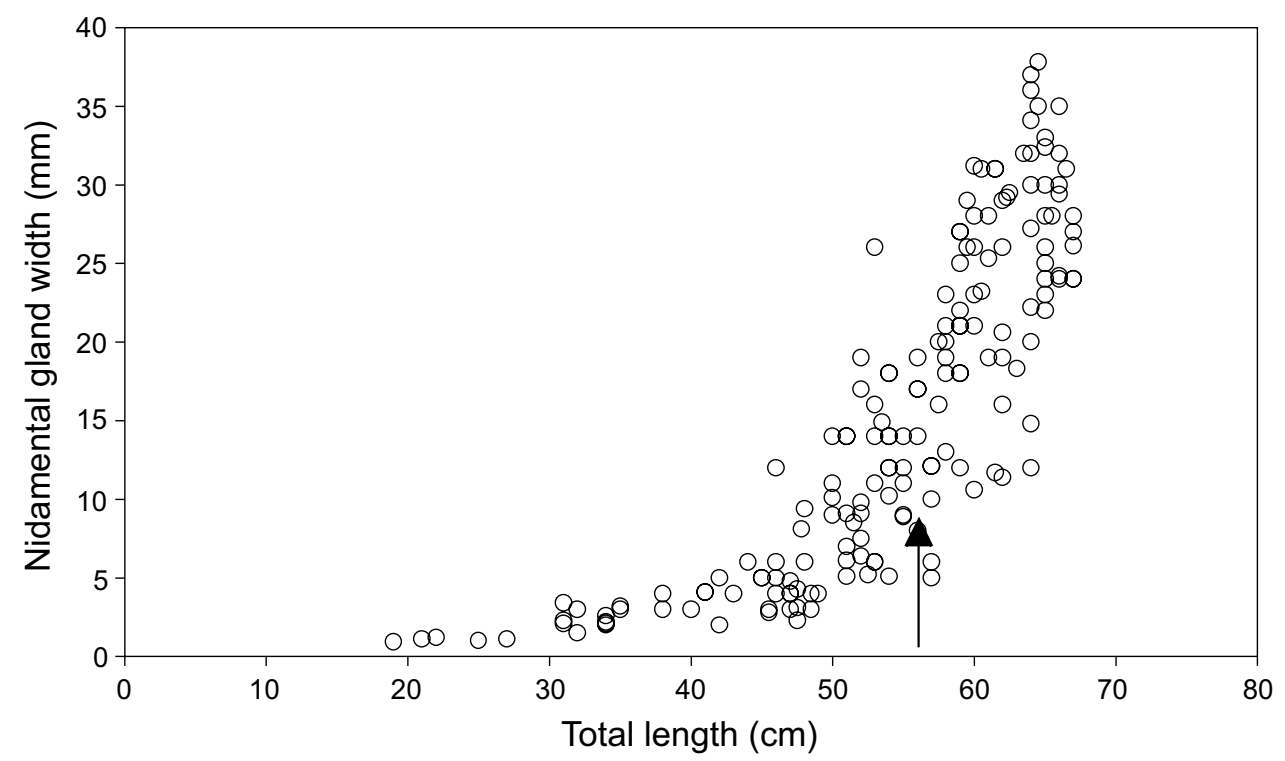

Fig. 23. Relationship between nidamental gland width $(\mathrm{mm})$ and total length $(\mathrm{cm})$ for $R$. montagui. Arrow on $\mathrm{X}$-axis denotes $50 \%$ maturity.

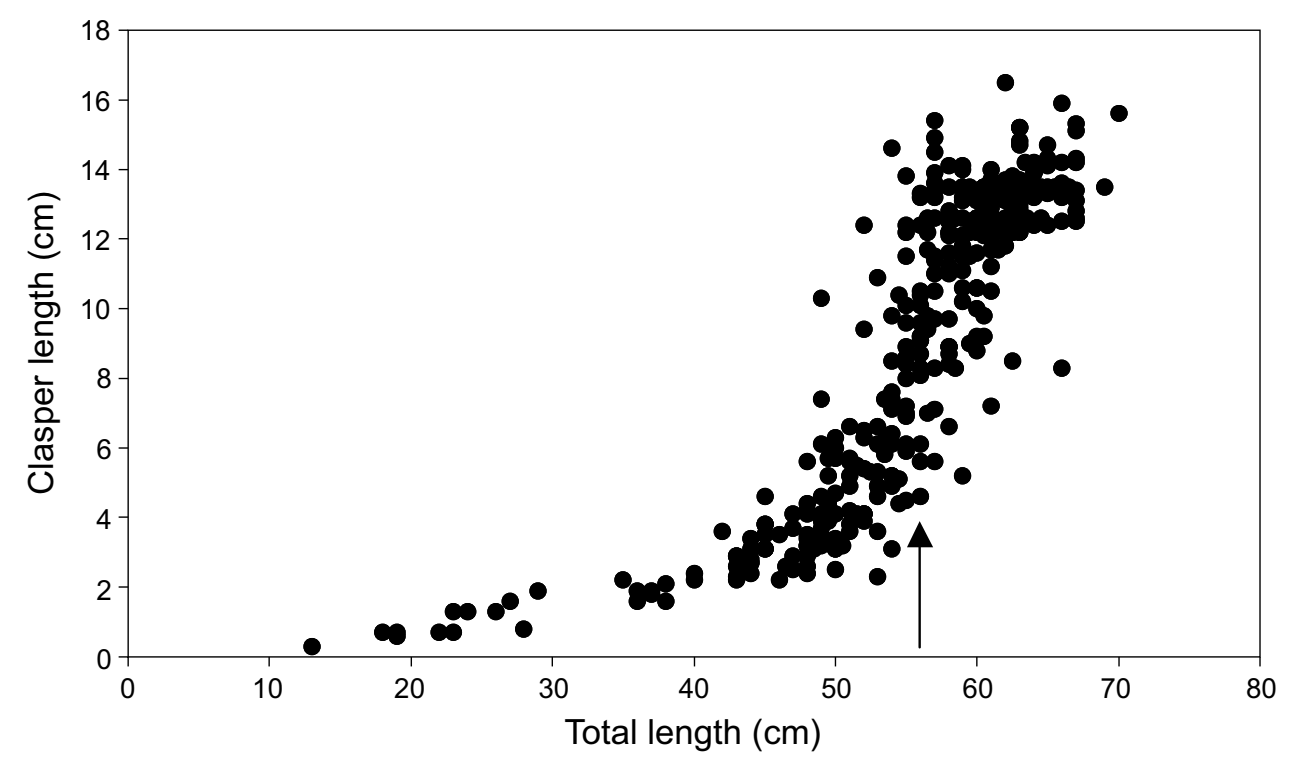

Fig. 24. Relationship between clasper length $(\mathrm{cm})$ and total length $(\mathrm{cm})$ for Leucoraja naevus. Arrow on $\mathrm{X}$-axis denotes $50 \%$ maturity. 


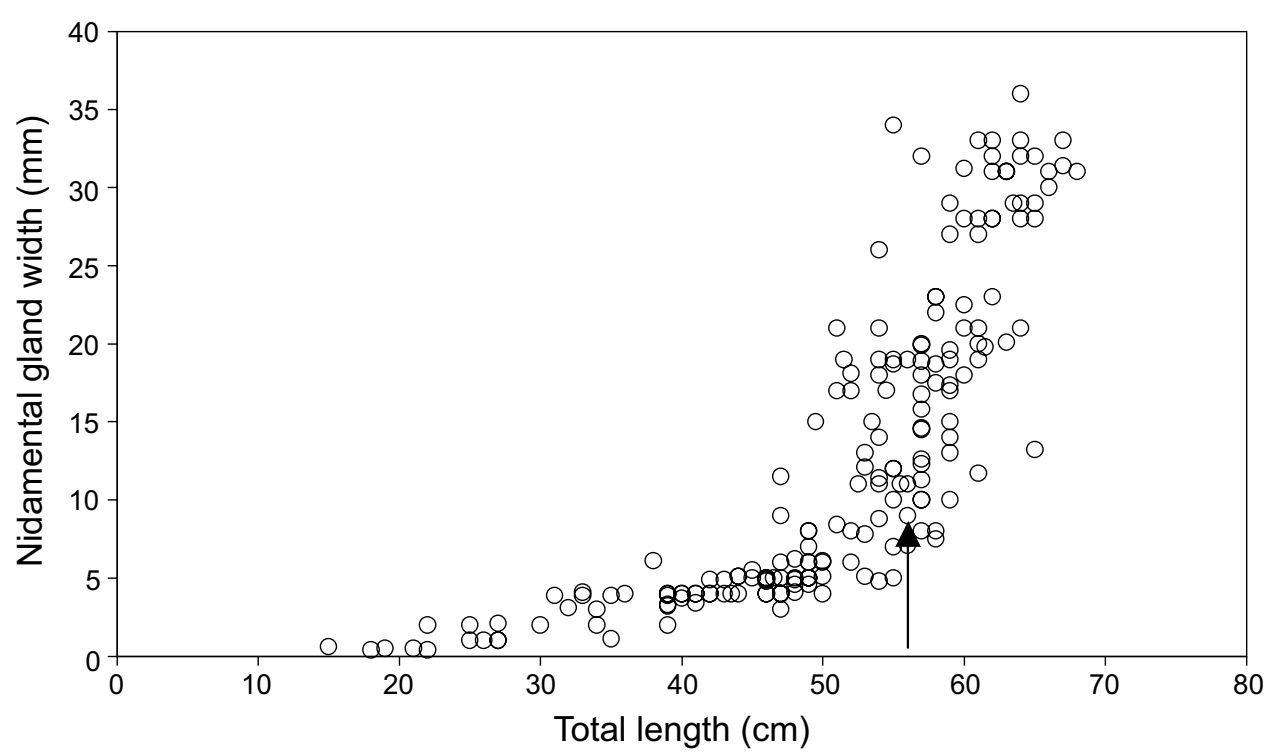

Fig. 25. Relationship between nidamental gland width ( $\mathrm{mm}$ ) and total length (cm) for L. naevus. Arrow on $\mathrm{X}$-axis denotes $50 \%$ maturity.

\section{References}

AGNEW, D. J., C. P NOLAN, J. R. BEDDINGTON, and R. BARANOWSKI. 2000. Approaches to the assessment and management of multispecies skate and ray fisheries, using the Falkland Islands fishery as an example. Can. J. Fish. Acquat. Sci., 57: 429-440.

ANDERSON, E. D. 1990. Fishery models as applied to elasmobranch fisheries. In: Elasmobranchs as Living Resources: Advances in the Biology, Ecology, Systematics and the Status of the Fishery. H. L. Pratt, S. H. Gruber and T. Taniuchi (eds.). U.S. Department of Commerce, Washington. NOAA Techn. Rep. NMFS, 90: 473-484.

ANON. 1999a. Ireland's Marine and Coastal Areas and Adjacent Seas: An Environmental Assessment, 388 p.

1999b. Case studies of the management of elasmobranch fisheries, R. Shotton (ed.), Rome. FAO Fish.Tech. Pap., 378 Part 1: 490 p.

ARMSTRONG, M. J., and R. P. BRIGGS. 1993. Role of fisheries science in management of Irish Sea fisheries. In: Managing Marine Fisheries: A case study of the Irish Sea, p. 59-70. Liverpool University Press, Liverpool.

BRANDER, K. 1981. Disappearance of common skate Raia batis from Irish Sea. Nature, 290: 48-49.

1988. Multispecies fisheries of the Irish Sea. In: Fish Population Dynamics. J. A. Gulland (ed.). Wiley J. \& Sons Ltd.

BRANDER, K., and D. PALMER. 1985. Growth rate of Raia clavata in the Northeast Irish Sea. ICES J. Cons., 42: $125-128$.

BRANDSTETTER, S. 1987. Age and Growth Validation of Newborn Sharks Held in Laboratory Aquaria, with Comments on the Life History of the Atlantic Sharpnose Shark, Rhizoprionodon terraenovae. Copeia, 2: 291-300.

CAILLIET, G. M., and S. TANAKA. 1990. Recommendations for Research Needed to Better Understand the Age and Growth of Elasmobranchs. In: Elasmobranchs as Living Resources: Advances in the Biology, Ecology, Systematics and the Status of the Fishery. H. L. Pratt, S. H. Gruber and T. Taniuchi (eds.) US Department of Commerce, Washington. NOAA Tech. Rep. NMFS, 90: 505-510.

CAILliET, G. M., K. G. YUDIN, S. TANAKA, and T. TANIUCHI. 1990. Growth characteristics of two populations of Mustelus manazo from Japan based upon crossreadings of vertebral bands. In: Elasmobranchs as living resources: advances in the biology, ecology, systematics, and the status of the fisheries. H. L. Pratt, S. H. Gruber and T. Taniuchi (eds.). US Department of Commerce, Washington. NOAA Tech. Rep. NMFS, 90: 167-176.

CAILLIET, G. M. 1990. Elasmobranch age determination and verification: an updated review. In: Elasmobranchs as living resources: advances in the biology, ecology, systematics and the status of the fisheries. H. L. Pratt, S. H. Gruber and T. Taniuchi (eds.). US Department of Commerce, Washington. NOAA Tech. Rep. NMFS, 90: 157-165.

CHANG, W. Y. B. 1982. A Statistical Method for evaluating the reproducibility of Age Determination. Can. J. Fish. Aquat. Sci., 39: 1208-1210.

CORLETT, J. 1990. Historical account of the fisheries. In: The Irish Sea: An Environmental Review. Part 2. Exploitable Living Resources. T. A. Norton and A. J. Geffen (eds.). Liverpool University Press. pp. 66-81.

DULVY, N. K., J. D. METCALFE, J. G. GLANVILLE, M. G. PAWSON, and J. D. REYNOLDS. 2000. Fishery Stability, Local Extinctions, and Shifts in Community Structure in Skates. Conservation Biol., 14: 283-293.

FAHY, E. 1989. Fisheries for Ray (Batoidei) in western statistical area VIIa, investigated through the commercial catches I. Department of Marine, Dublin. Irish Fish. Investigations, Ser. B (Marine), 34: 14 p. 
1991. The southeastern ray Raja spp. fishery, with observations on the growth of rays in Irish waters and their commercial grading.Department of Marine, Dublin. Irish Fish. Investigations, Series B (Marine) 37: $18 \mathrm{p}$.

GALLAGHER, M. J. 2000. The fisheries biology of commercial ray species from two geographically distinct regions. Ph.D. Thesis, Department of Zoology, University of Dublin, Trinity College, Dublin 2, Ireland.

HOLDEN, M. J. 1972. The Growth Rates of Raja brachyura, $R$. clavata and $R$. montagui as determined from tagging data. ICES J. Cons., 34: 161-168.

HOLDEN, M. J., and M. R. VINCE. 1973. Age validation studies on the centra of Raja clavata using tetracycline. ICES J. Cons., 35: 13-17.

HOLDEN, M. J. 1974. Problems in the Rational Exploitation of Elasmobranch Populations and Some Suggested solutions. In: Sea Fisheries Research. F. R. Harden Jones (ed.). Elk Science, London, 117-137.

HOLDEN, M. J. 1977. Elasmobranchs. In: Fish Population Dynamics. G. A. Gulland (ed.), Wiley, London, p. 187-215.

KULKA, D. W., and C. M. MIRI. MS 2003. The status of Thorny skate (Amblyraja radiata Donovan, 1808) in NAFO Divisions $3 \mathrm{~L}, 3 \mathrm{~N}, 3 \mathrm{O}$ and Subdivision 3Ps. NAFO SCR Doc., No. 57, Serial No. N4875, 100 p.

MARTIN, L. K., and G. M CAILLIET. 1988. Age and Growth determination of the bat ray, Myliobatis californica Gill, in Central California. Copeia, 3: 762-773.

MARQUADT, D. W. 1963. An algorithm for least squares estimation of non-linear parameters. Society for Industrial and Applied Mathematics, 11(2): 431-441.

NOTTAGE, A. S., and J. PERKINS. 1983. Growth and maturation of roker Raja clavata L. in the Solway Firth. The Fisheries Society of the British Isles, p. 43-48.

OFFICER, R. A., A. GASON, T. I., WALKER, and J. G. CLEMENT. 1996. Sources of variation in counts of growth increments in vertebrae from gummy shark, Mustelus antarcticus, and school shark, Galeorhinus galeus: implications for age determination. Can. J. Fish. Aquat. Sci., 53: $1765-1777$.

PAWSON, M., and M. VINCE. 1999. Management of shark fisheries in the Northeast Atlantic. In: Case studies of the management of elasmobranch fisheries. R. Shotton (ed.), Rome. FAO Fish. Tech. Pap., No. 378, Vol. 1: 1-46.

PRAGER, M. M., S. B. SAILA, and C. W. RECKSIEK. 1987. FISHPARM: a micromputer program for parameter estimation of nonlinear models in fishery science. Department of Oceanography, Old Dominion University, Norfolk, VA., Tech. Rep., 87-10: 1-37.

RYLAND, J. S., and T. O. AJAYI. 1984. Growth and Population Dynamics of three Raja species (Batoidea) in Carmarthen
Bay, British Isles. ICES J. Cons., 41: 111-120.

SCHWARTZ, F. J. 1983. Shark ageing methods and age estimation of Scalloped Hammerhead, Sphyrna lewini, and Dusky, Carcharhinus obscurus, sharks based on vertebral ring counts. In: Proceedings of the International Workshop on Age determination of Oceanic Pelagic Fishes: Tunas, Billfishes and Sharks, E. D. Prince and L. M. Pulos (eds.), US Department of Commerce, Washington. NOAA Tech. Rep. NMFS, 8: 157-166.

STEHMANN, M. 1987. Quick and dirty tabulation of stomach contents and maturity stages for skates (Rajidae), squaloid and other ovoviviparous and viviparous species of shark. American Elasmobranch Society Newsletter, 3: 5-9.

STEVEN, G. A. 1936. Migrations and Growth of the Thornback Ray (Raia clavata L.). J. Mar. Biol. Assoc. U.K., 20(3): 605-614.

TANAKA, S., G. M. CAILLIET, and K. G. YUDIN. 1990. Differences in Growth of the Blue Shark, Prionace Glauca: Technique or Population. In: Elasmobranchs as Living Resources: Advances in the Biology, Ecology, Systematics and the Status of the Fisheries, U.S. Department of Commerce, Washington, 90: 177-188.

TAYLOR, A. J., and M. J HOLDEN. 1964. The preparation and use of vertebrae for age determination in rays. In: ICES C.M., 145: 1-3.

VON BERTALANFFY, L. 1938. A quantitive theory of organic growth (inquiries on growth laws. II). Human biology 10: 181-213.

WALKER, P. A., and J. R. G HISLOP. 1998. Sensitive skates or resilient rays? Spatial and temporal shifts in ray species composition in the central and north-western North Sea between 1930 and the present day. ICES J. Mar. Sci., 55: 392-402.

WALKER, P. A. 1999. Fleeting Images Dynamics of North Sea Ray Populations, PhD. Thesis. University of Amsterdam, Netherlands Institute for Sea Research, Texel, $142 \mathrm{p}$.

WILLIAMS, B. R. H., E. J PERKINS, and A. HINDE. 1965. The Biology of the Solway Firth in relation to the movements and accumulation of radioactive materials. III. Fisheries and Food Chains. Her Majesty's Stationery Office, United Kingdom Atomic Energy Authority, London.

YUDIN, K. G., and G. M. CAILLIET. 1990. Age and Growth of the Gray Smoothound, Mustelus californicus, and the Brown Smoothound, M. henlei, sharks from Central California. Copeia, 1990(1): 191-204.

ZEINER, S. J., and P. Wolf. 1993. Growth Characteristics and estimates of Age at Maturity of Two Species of Skates (Raja binoculata and Raja rhina) from Monterey Bay, California. In: Conservation Biology of Elasmobranchs. S. Branstetter (ed.), U.S. Department of Commerce, Washington. NOAA Tech. Rep. NMFS, 115: 87-99. 